http://economix.fr

\title{
The Paradox of Plenty: A Meta-Analysis
}

Document de Travail

Working Paper 2016-14
Magali Dauvin David Guerreiro

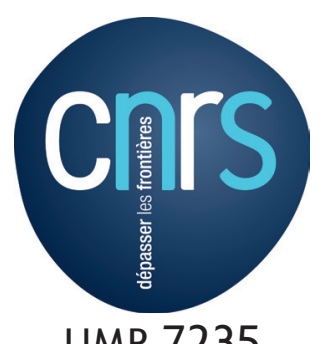

UMR 7235
Université de Paris Ouest Nanterre La Défense (bâtiment G) 200, Avenue de la République 92001 NANTERRE CEDEX université

Paris Ouest 


\title{
The Paradox of Plenty: A Meta-Analysis*
}

\author{
Magali Dauvin $^{\dagger} \quad$ David Guerreiro ${ }^{\ddagger}$
}

March 10, 2016

\begin{abstract}
Since Sachs and Warner's seminal paper in 1995, a conventional wisdom has spread in the academic literature stating that a high endowment in natural resources may be detrimental for growth. The great heterogeneity of development paths followed among resource-rich countries has shown that the resource curse was not always inevitable, and that there existed ways to make the most of one's natural wealth. We identified three sources of heterogeneity in the literature: the use of abundance and intensity measures, the account for appropriability aspects of resources and finally, the role of institutions. In this paper, we aim at providing quantitative results on the magnitude of the link between natural resources and growth found in the literature, as well as discussing, on quantitative bases, whether the sources of heterogeneity are significant. To this end, we implement a meta-analysis based on 67 empirical studies that investigate the link between natural resources and growth, totaling 1405 estimates. The results show a "soft" curse that may be reverted together with the importance of institutions in mitigating the curse.
\end{abstract}

Keywords: Meta-analysis; Resource Curse; Natural Resources; Appropriability; Institutions

JEL Codes: C82, O11, O13 .

${ }^{*}$ We are grateful to Guillaume Bazot, Benoît Chèze, Valérie Mignon, Antoine Terracol and Gilles de Truchis for many insighful comments and suggestions. All errors remain ours.

${ }^{\dagger}$ EconomiX-CNRS, University of Paris Ouest, 200 avenue de la République, 92100 Nanterre, France. Email: magali.dauvin@gmail.com.

${ }^{\ddagger}$ LED, University Paris 8, 2 rue de la Liberté, 93526 Saint-Denis, France. Email: david.guerreiro@univ-paris8.fr. 


\section{Introduction}

Countries highly endowed with a bounty of natural resources have tended to fail to benefit from them, and sometimes have performed worse than less-endowed countries. This is some conventional wisdom that has spread in the academic literature since the mid-1990s: the paradox of plenty (Gelb, 1988; Barro, 1991; DeLong and Summers, 1991; King and Levine, 1993; Auty, 1993). One recurring example is given by Nigeria's poor performance albeit its huge oil wealth, while diamonds-rich Botswana has managed to fall between the cracks. Since Sachs and Warner's famous paper in 1995, an extensive literature, both theoretical and empirical, has emerged on the resource curse. The great heterogeneity of development paths followed among resource-rich countries has shown that the resource curse was not always inevitable, and that there existed ways to make the most of one's natural wealth.

Van der Ploeg (2011) offers an extensive survey with both empirical evidences and theoretical considerations explaining why some countries suffer from their natural resource endowment, while others do not. The detrimental effects of natural resources on the economy have been highlighted through two scopes: a market-based viewpoint focusing on macroeconomic mechanisms, and a political economy approach stressing the role of institutions (Deacon, 2011; Deacon and Rode, 2015) that has gain a lot of importance in the last decade 1

The Dutch disease has surely been among the oldest explanations of the resource curse, building on the gas field discovered by the Netherlands in the 1970s and implications thereof. A revenue windfall leads to a contraction of the manufacturing sector because of an increase in labor costs appreciating the real exchange rate (see Corden and Neary (1982) for further explanations). The subsequent loss in learning-by-doing in the non-resource traded sector may also add existing pressures on this sector. In the same vein, increasing world commodity prices has led countries, especially in Latin America in the 1970s, to follow unsustainable policies. Political scientists have put emphasis on the inability of government actors to see further than "good times", reflected in over-expanding public sectors (Lane and Tornell, 1999; Auty, 2001) sometimes financed by excessive borrowing causing "debt-overhangs" (Manzano and Rigobon, 2001). The problem arising is that it becomes "impossible to finance once resource revenues dry up" (van der Ploeg, 2011: 392). These issues are all the more important since many resource-rich economies fail to transform their stock of natural wealth into more labor and capital intensive wealth, and experience negative saving yet indispensable to foster growth (Atkinson and Hamilton, 2003), while facing credit constraints (Beck, 2010). The risks inherent to resource-rich economies evoked above also lay in the high volatility of commodity prices because export revenues exhibit a low price elasticity, which according to van der Ploeg and Poelhekke (2009) "seem to be the quintessence of the resource curse".

\footnotetext{
${ }^{1}$ We acknowledge the fact that both views are highly - if not completey --entangled, but this distinction is in accordance with the literature's evolution. van der Ploeg (2011) provides multiple empirical evidences for each proposition mentioned in the text that follows, but we focus on the potential negative outcomes resulting from natural resource wealth, without paying attention to the implicit factors that can alleviate the curse. Section 2 will provide a more in-depth review of the empirical findings.
} 
High volatility generates large real exchange rate fluctuations, less investment, especially in countries where financial development is lagging (Aghion et al. , 2009), consequently translating into lower productivity growth. All these factors may hamper growth in the end, especially in developing countries where terms-of-trade fluctuations are twice as large as in developed countries (Baxter and Kouparitsas, 2006). Finally, together with recurring blind and over-optimistic governments about their relative natural richness, the neglect of investment in human capital and its effects on growth have been emphasized in Gylfason (2001).

The cornerstone of the political economy approach is that natural resources may be growthdeterring because they foster rent-seeking behavior. Institutions are at the heart of this relation, but so far, the role they play is not clear-cut, since it seems to be an endogeneity problem. On the one hand, the main strand of the literature advocates that poor institutions are primarily what foster the rent-seeking behavior in a natural resource bonanza context. Lane and Tornell (1996) and Tornell and Lane (1999) pine down the voracity effect - a particular form of rent-seeking where powerful groups have the ability of hijacking and grabbing natural resources to their advantage - that occurs within a poor "legal-political institutional framework" (altered property rights and market imperfection) and in the presence of fractionalization. Torvik (2002), or Mehlum et al. (2006), put forward an entrepreneurship diversion effect in which institutions determine the behavior of an entrepreneur. When institutions are weak, profits retrieved from resource appropriation tend to be higher than from pure production. Hence entrepreneurs are incentivized to become resource-grabbers rather than wealth-producers, hampering growth. On the other hand, a low-quality institutional framework is instead seen as a result of rent-seeking (Karl, 1997; Ross, 2001). When resource rich countries are fractionalized, competition between groups for resource appropriation leads to institutions damaging, which in turn negatively affects growth through the lens of property-rights corrosion (Hodler, 2006). Other channels than property-rights may also be at work, for example corruption, as documented in Brazil by Caselli and Michaels (2009), or rigged elections with bribed voters (Acemoglu and Robinson, 2006), and bought off political challengers (Acemoglu et al. , 2004). On the whole, democracy seems to be harmed as highlighted by Ahmadov (2013), whose meta-analysis evidences a strong negative relationship between democracy and oil-wealth.

So far, traditional reviews of literature put forward that (i) the occurrence of resource curse is not clear-cut since "empirical evidence suggests that either outcome [curse or blessing] is possible" (van der Ploeg, 2011), and that (ii) several factors such as resource measurement, institutions, policy, and financial development (among others) seem to play a central role.

According to us, if the traditional literature review is very useful since it pictures the state of the art, discusses the theoretical backgrounds, and provides some new guidelines for further research, it suffers from a major shortcoming when turning to empirical considerations, as in the paradox of plenty context: quantification. Indeed, it is unable to determine how large the curse or the blessing can be, nor the relative importance of each factor in fueling 
or mitigating the curse (blessing), and even less the existence of a publication bias.2 Because of these structural weaknesses, conventional literature reviews may present incomplete and/or flawed conclusions. The aim of this paper is to overcome the shortcomings previously mentioned and provide quantitative results on the magnitude of the link between natural resources and growth found in the literature, as well as discuss, on quantitative bases, the sources of heterogeneity across studies' findings. As this quantitative review is specifically designed to integrate and evaluate econometric estimates, meta-regression analysis (MRA) appears to be the best technique to fulfill this goal.

First, MRA is a systematic literature review where all empirical studies have to be accounted for (unless solid justification), rendering it more immune to selection bias than conventional literature review. Another interesting fcharacteristic lies in the quantitative assessment it offers. Thanks to econometric techniques, one can obtain an estimation of the effect studied (here the resource curse) revealed by the meta-average, along with a discussion of each heterogeneity factors reflected in magnitude and signification of the respective coefficients. MRA benefits from an increased statistical power due to the merge of the different samples of primary regressions. Finally, MRA is also characterized by replicability, ensuring an additional objectivity.

In short, reviewing literature with a meta-regression involves three main steps, starting with an exhaustive search of all empirical studies dealing with the topic of interest, that on a second stage enables to code a dataset constituted by an explanatory variable (containing the effect-sizes) and a set of moderators (reflecting the potential heterogeneity between and within primary studies), necessary to run, in a third step regressions and provide quantitative assessments. If meta-regression is a powerful tool, it also suffers from a few shortcomings that we have to keep in mind when interpreting the results. In particular the second step is crucial since there is necessary a loss of information when transforming characteristics from primary literature to quantitative or dummy variables (this problem is further developed in Section 3).

Although meta-analysis has been employed in the medical field for quite some time with the seminal work of Pearson (1904), it has only spread to social sciences in the early eighties (Glass, 1981). Stanley and Jarrell (1989) first adapted and applied meta-analysis to economics, giving rise to meta-regression analysis. Since then, hundreds of papers have adopted this quantitative literature review to deal with topics as diverse as the growth-education nexus (Benos and Zotou, 2014), macroeconomic impacts of FDI (Iwasaki and Tokunaga, 2014) or minimum wage effects (Doucouliagos and Stanley, 2009). Regarding the paradox of plenty literature, only Havranek et al. (2015) have implemented a MRA, to our best knowl-

\footnotetext{
${ }^{2}$ Simply put, "publication bias is the term for what occurs whenever the research that appears in the published literature is systematically unrepresentative of the population of completed studies" (Rothstein, et al., 2005). In social sciences, there is a tendancy to prefer significant findings rather than unsignificant ones. In medical sciences, some results may be more desirable than others regarding for example a drug's second-round effect. In both cases, it can lead to a publication bias in the existing literature.
} 
edge. In our work, we encompass a wider dataset (67 studies containing 1405 estimates vs. 33 studies containing 620 estimates) with alternative measures of resources, and we go further on the role of institutions by implementing a separate MRA to interaction results studying the effects on growth of resources when conditioned by institutions.

The remainder of the paper is as follows. In Section 2, we review the articles used in our MRA. Some descriptive statistics are provided and we discuss the different parti-pris of authors. In Section 3, we introduce the dataset and the econometric issues. We explain the way we code variables, the different categories therein and principal features. We also propose solutions to the main econometric pitfalls and bring out the estimators. Section 4 is devoted to the results and their interpretation. We go deeper into the role of institutions in Section 5 by carrying a specific meta-analysis. Finally we confront our results to previous literature, and draw conclusions in the last section.

\section{Primary Studies}

\subsection{Data set description}

A comprehensive search of the literature via the software Publish or Perish revealed a large amount of articles responding to the following keywords: "resource curse", "economic growth" , "natural resources". ? $^{3}$ We choose 1995 (Sachs and Warner's seminal paper) as the starting year of the search for studies and end our search in December 2015, totaling 21 years of academic research. On these 181 studies, sixty-seven papers met our requirements consisting in (i) an empirical assessment of the link between natural resources and economic growth; (ii) an investigation on the existence of the resource curse with a natural resource variable that is continuous, and the dependent variable defined in growth terms; and finally (iii) the use of an econometric framework that is linear in the parameters.

This leaves us with 67 studies that aim at assessing whether the resource curse exists, and if so, its transmission channels. The entire database is available upon request to the authors, and all the papers that are used here may be found in Section A.

In Figure 1, we report all the effect sizes found in our dataset, with the studies depicted on the vertical axis and the corresponding estimated effect sizes therein, on the horizontal axis. All estimates are not directly comparable, this is the reason why we depicted the partial correlation coefficients (PCC). ${ }^{4}$ Roughly speaking, the dots that lie on the left of the vertical line in 0 (horizontal axis) tend to evidence a resource curse while it is the opposite on the right. In other words, the closer to -1 (resp. 1), the stronger the resource curse (resp. blessing). The visual insight we get from this plot is that correlations are quite dispersed among the [-1;1] interval, they range from -0.80 to 0.69 (Table 2). Moreover, dispersion is

\footnotetext{
${ }^{3}$ Studies were retrieved from Google Scholar and EconLit.

${ }^{4}$ See Section 3 for a proper definition of the PCC.
} 
present not only between the 67 studies but also on a within-study basis.

Figure 1: Heterogeneity of Results

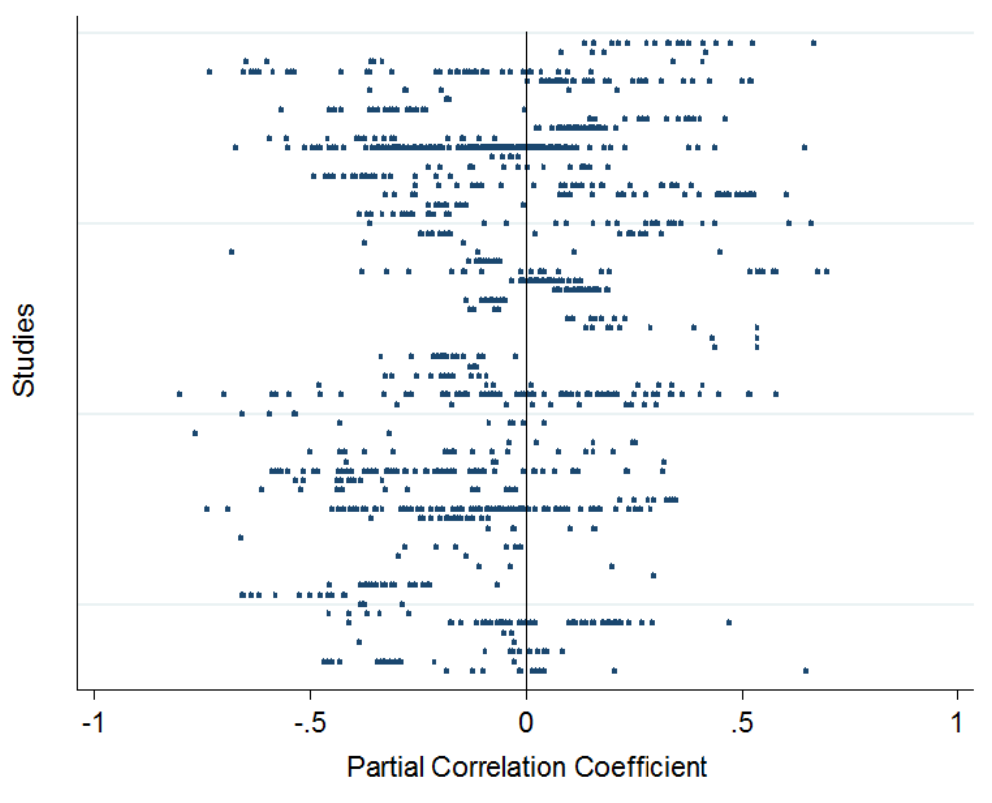

Figure 2 depicts a funnel plot which is a scatter plot of the effect sizes estimated from individual studies (horizontal axis) against a measure of study size (vertical axis); here, the standard error of the effect sizes (this is also know as the FAT-PEESE test). The diagonal lines represent the "pseudo" 95\% confidence limits around the summary effect size for each standard error on the vertical axis. In the absence of heterogeneity (or publication bias), $95 \%$ of the studies should lie within the funnel defined by the straight lines. Here, a high number of points stands outside of the diagonals, and most especially on the left-hand side of the vertical line in 0 . This second visual insight confirms the high heterogeneity present in our sample, and the factors driving the discrepancies are studied in the next section.

\subsection{Heterogeneity in primary studies}

\subsubsection{Abundance versus Dependence}

For almost a decade, economists have equated resource abundance and resource dependence 5 or at the very least, the discrimination between the two did not raise much concern as illustrated by Sachs and Warner (2001: 5): "For most countries, however, changes in the definition of natural resources is not as quantitatively important as one may think". Moreover, the concept of resource abundance seems unclear and as Lederman and Maloney note, "there is limited consensus on the appropriate empirical proxy for measuring resource abundance" (2003: 4). One simple illustration is that studies tend to use interchangeably all types of natural resource variables to assess the robustness of their empirical strategy, regardless of

\footnotetext{
${ }^{5}$ The preferred measure was actually the one allowing for the largest data set.
} 
Figure 2: Funnel plot

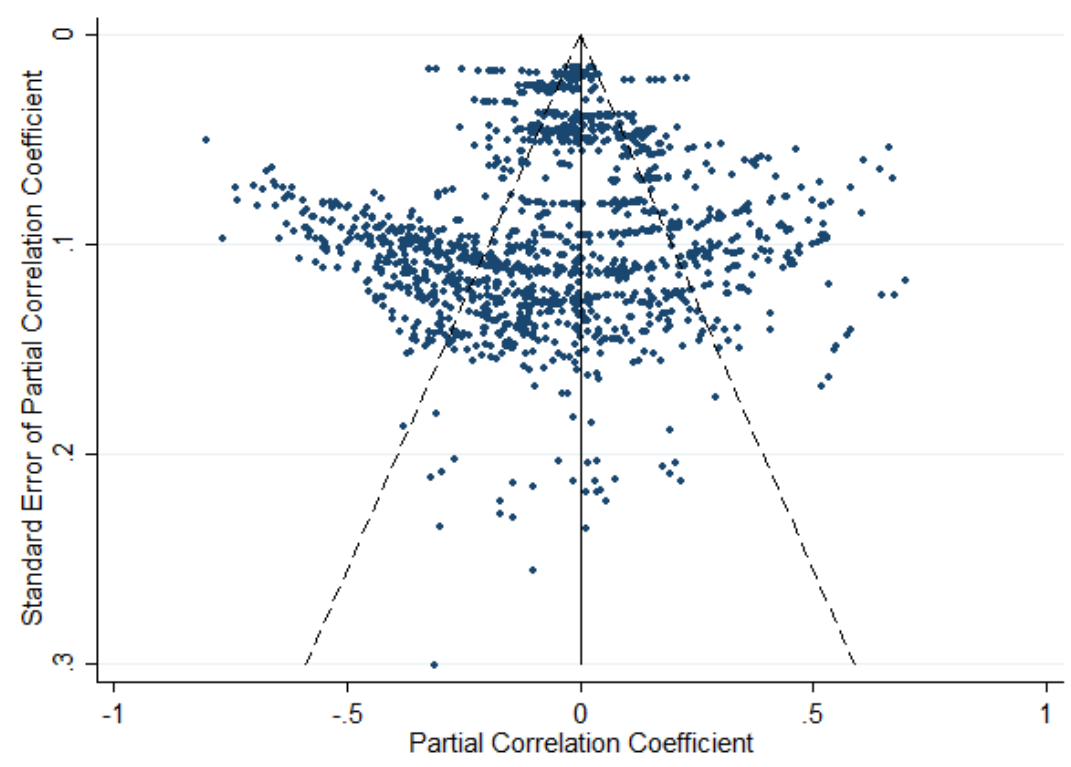

its economic signification. Not surprisingly, many papers followed Sachs and Warner's strategy using the share of primary exports over GDP to assess the existence of the resource curse.

Let us now go back to the original concept of the resource curse: it states that countries highly endowed in natural resources have tended to experience more fragile economic performance than their resource-poor counterparts. Therefore, if one wishes to quantify the resource curse as previously defined, then one should first consider measures that are the closest proxies for wealth and not that of intensity and specialization, which is the case of export or GDP-based variables. While resource abundance refers to a gift of nature, endowment, wealth (ie. stock); resource dependence reflects more the extent to which a country is reliant on the production and exports of its natural resources to sustain its consumption and development (ie. reliant on money flows). There are no reasons for abundance to lead to dependence in the first place. Indeed, there exist examples of resource-rich countries exhibiting low economic dependence on their resources as well as not so abundant countries with an extreme specialization on the production of primary products (Brunnschweiler, 2008; Kropf, $2010)$.

Interpretation of the resource curse thus may differ a lot as "changes in its definition sensitively [could] affect the outcome of empirical analyses" (Kropf, 2010: 108). Our set depicts that resource abundance measures measured by the share of natural capital (it includes geology, soils, air, water and livestock) and reserves, are associated with higher growth, while resource intensity, generally illustrated by the share of commodity exports over GDP or total exports, tends to impede growth. Sachs and Warner $(1995,1999,2001)$ do not demonstrate that there is a resource curse per se, rather they show that a higher specialization 
in the natural resource sector generally goes in hand with poor development. While it is easy to sort the measures previously mentioned, there is no consensus on how production and rents of natural resources should be considered as they are a mix of both stocks and flows concepts. For instance, Norman (2009) defines rents as "the flow of income derived from the resource stock at some point in time". If we divide natural resource measurements between (i) all scaled-variables that reflect intensity measures (DEPENDENCE) and (ii) stocks that may include rents and production (ABUNDANCE), we get the picture depicted in Table 1 .

Table 1: Effect sizes

\begin{tabular}{lccc}
\hline & Abundance & Dependence & Total \\
Total & 482 & 923 & 1405 \\
& & 421 & 659 \\
SignificANT & 238 & 0.46 & 0.46 \\
\% Total & 0.49 & 87 & 258 \\
Positive & 171 & 0.21 & 0.4 \\
\% signif. & 0.72 & 334 & 401 \\
NeGATIVE & 67 & 0.79 & 0.6 \\
\% signif. & 0.28 & & \\
\hline
\end{tabular}

Notes. Signif. means significance at the $5 \%$ confidence level.

By definition, natural resource variables scaled by the size of the economy (e.g. total exports, GDP) imply that they highly depend on "economic policies, institutions that produced them" (Brunnschweiler and Bulte, 2006: 249). From a purely econometric viewpoint, the problems most likely to arise - particularly in cross-country regression analyses (two-third of our sample) — are those of endogeneity and omitted variable bias. However, reserves are not immune to endogeneity, only to a lesser extent, as they depend on technological standards and on investments that are made (Norman, 2009). These endogeneity issues put aside, the political economy literature contributed a lot to the understanding of the main differences between the concepts of abundance and dependence. In a nutshell, resource wealth may shape the institutional context such that it ends up hampering growth, while resource dependence is most likely to be detrimental to growth as a result of the poor institutions that are in place (Melhum et al., 2006; Norman, 2009). Finally, once resources are allowed to impact economic growth not only by themselves but via crowding-out effects, either through their impact on savings (Atkinson and Hamilton, 2003), investment (Gyflason and Zoega, 2006; Papyrakis and Gerlagh, 2006), human capital (Gyflason, 2001) or institutions (Brunnschweiler and Bulte, 2008), their existence per se does not appear as a burden anymore. It seems that abundance does not necessarily induce a lagging economic development; it is when abundance turns into too much dependence that it can be detrimental.

We identified about six main ways of taking natural resources into account: from exports to production, employment, through reserves, rents, and natural capital. These measures are 
generally expressed either as a share in national income or total exports, or in per capita terms.

\subsubsection{A question of Appropriability}

A theme that has been less controversial in the literature compared to the debate previously mentioned revolves around the inherent nature of the resources considered. More precisely, the distinction lies between extracted and produced primary products, namely "point-source" and "diffuse" resources, respectively. Point-source resources, characterized by the fact that they are clustered geographically and relatively easy to monitor and control, favor appropriative behavior either from producers or governments (Boschini et al., 2007)..$^{6}$ Oil, minerals, precious metals, and crops such as coffee, cocoa fall under this category. The non-renewable feature of oil and mineral resources is not to be left aside as it raises even more rent-seeking incentives, in part due to uncertainty about the amount of resources that is left to extract (Pindyck, 1993). Although renewable and diffuse in terms of production, coffee and cocoa are considered as point-source resources on the basis that they are subject to concentration in ownership (Murshed, 2004). Produced resources like rice, wheat or livestock (animals) are more diffuse in that their production results of local farms and thus are less prone to lobbying over their control or special favors from the power in place (Brunschweiler and Bulte, 2008).

There is undisputable evidence that fuel and mineral wealth (point-source resources in general) have a more detrimental impact on one country's development compared to other natural resources (Auty, 1997, 2001; Costantini et al., 2008; Norman, 2009; Williams, 2011). Also, oil and mineral resource measures are negatively associated with institutional quality, which is not the case for diffuse resources (Sala-i-Martin and Subramanian, 2003; Isham et al., 2005). The rationale behind this regularity is strongly linked to political economic considerations (Robinson et al., 2006): the "rentier effect" is closely related to the notion of appropriability. The appropriability of a resource refers the extent to which its control allows "to realize large economic gains, within a relatively short period of time" (van der Ploeg, 2011: 384) and is critical in understanding why some resource-rich countries sharing the same natural resources follow different development paths.

Boschini et al. (2007) define two dimensions of appropriability. The first one is the legal and political context in which the resource is produced, which corresponds to "institutional" appropriability and states that resource dependence hampers growth only under poor institutions. Physical and economic characteristics of the resources compose what is referred to as "technical appropriability", and allow capturing the rent-seeking incentives that pointsource resources may generate. Indeed, it states the existence of non-monotonic impact of resource dependence on economic growth via the quality of institutions (Melhum et al., 2006). More particularly, countries with poor institutions are expected to have the largest negative effects of their resources, while countries endowed with these resources and which have good institutions are predicted to have large gains from them.

\footnotetext{
${ }^{6}$ Facilitated storing and transportation is also an important feature.
} 


\subsubsection{The role of Institutions}

Institutions have already been well recognized as being crucial determinants of economic development. The profits that result from natural resource wealth are such that well-established institutions are required so that they benefit to the country's people. The political economy literature has been increasingly solicited to explain why countries that are similarly endowed follow opposite development paths, as the famous Nigeria-Botswana comparison illustrates. Empirically, the institutional channel of the natural resources-economic growth nexus is taken into account with interacted terms. Most of the studies concerned find that good institutions prevent or at least reduce the incentives to engage in rent-seeking behavior. The interaction variable (Institutions $\times$ Natural Resource) is positively associated with economic growth.

The institution variables found in the literature may be distinguished by the moment they intervene in the system. Institution quality, whether high or low, matters on the way natural resource revenues are enjoyed the first time (after a discovery, etc.). These features are incorporated in indicators that reflect the rules constraining the government's behavior, more generally, the constitutional framework. The Polity IV index, that measures the country's democracy level (Boschini et al., 2013; Bjorvatn et al., 2012 - Polity2); the checks and balances, which measure the extent to which politicians may be restrained from abusing office for political purpose (Brückner, 2010); the rule of law (Alexeev and Conrad, 2009); electoral rules (Andersen and Aslaksen, 2008) are examples of such institutional quality indices.

The other aspect of institutional quality relates to government actions and their effectiveness in harnessing windfalls. Hence, rent-seeking incentives — permitted by poor governance - may deteriorate institutions such that revenues are cornered and whether a country is more prone towards grabber-friendly actions rather than producer-friendly is a key point (Melhum et al., 2006). Variables that contain include this aspect include composite indices

calculated as an unweighted average of 3 or more characteristics such as the one calculated from the Political Risk Services database (Melhum et al., 2006, Crutzen and Holton, 2010); the International Country Risk Guide index (Boschini et al., 2013; Bjorvatn and Farzanegan, 2013). Examples of characteristics retained in those measures are the bureaucratic quality, the corruption in government, the risk of expropriation, and government repudiation of contracts, etc. All institutions that benefit rent-seeking activities tend to exacerbate the impact natural resources might have on a country's economic performance. Better governance, as well as voice and accountability, transparent budget are examples of "economic" institutions that help reverse the resource curse into a blessing (Farhadi et al., 2012; El Anshasy and Katsaiti, 2013).

From a purely econometric viewpoint, there are two main issues when studying the effects of natural resources, institutions, and their interaction on economic growth. First of all, the development process may endogenously determine institutions. This type of endogeneity is commonly dealt with the use of instruments such as the fraction of people that speaks English or a West-European language, ethnic fractionalization, settler's mortality, and the 
distance from equator (latitude) in first-stage instrumental variable regressions (Boschini et al., 2007; Alexeev and Conrad, 2009, Brückner, 2010). Some authors prefer to use variables measured at some point in time, and generally at the beginning of the period (Boschini et al., 2013). Another issue - in line with both aspects of institutional quality evoked above - lays in the fact that institutions and natural resources may affect one another. On the one hand, resource extraction or knowledge of the rents it can generate may determine the quality of institutions. On the other hand, the institutional context may determine the extent to which resources are extracted and their rents used. To overcome this issue, the solution consists in the use of two-stage procedures to first estimate the impact of resource abundance on institutions and then infer the effect of institutions on economic growth (Salai-Martin and Subramanian, 2003; Isham et al., 2005). In this case, resource wealth is found to harm institutions, which in turn leads to poor economic performances.

\section{Coding and Econometric Issues}

\subsection{The construction of variables}

As mentioned in the introduction, the coding of variables is a crucial step. It allows the transformation of the different characters identified among primary literature into testable features. However, this proceeding is not without problems, the main issue raised being the loss of information. This necessarily happens when primary literature reports only limited material about key-determinants (for example data sources, samples under study, econometric techniques). In this sense the quality of a MRA is conditioned by the quality of primary studies. There is also a trade-off between the number of moderators coded (that accounts for intra and inter study heterogeneity), and saving degrees of freedom. As we evidence further, multi-collinearity may heavily hamper the scope of the results, and meta-analysts are forced to reduce information in order to get robust conclusions.

The dependent variable is crucial in MRA because it has to measure the relationship we are interested in, in other words, the effect-size of natural resources on growth. A special care should be provided since the construction of the dependent variable cannot be reduced to simply retrieving and pooling the estimated coefficients found in the primary studies. Effectsizes must gauge exactly the same purpose implying them to be expressed in a common metric. The main reason impeding to directly use coefficient estimates is that functional forms used among primary literature on resource curse are not homogeneous: while some rely on linear, others rely on log-linear or log-log functional forms. In order to overcome the problem, we transform these coefficients (respectively semi-elasticities and elasticities) into Partial Correlation Coefficients (hereafter PCC), as follows:

$$
P C C_{i j}=\frac{t_{i j}}{\sqrt{t_{i j}^{2}+\mathrm{df}_{i j}}}
$$

where $t$ denotes the reported effect size's t-statistic of the $i$-th regression in the $j$-th study 
and df the degrees of freedom associated to the former. PCC measure the direction and the strength of the association between natural resources and economic growth, ceteris paribus (Stanley and Doucouliagos, 2012). We also derive the standard-errors from PCC, since they are needed as explanatory variables to control for publication bias:

$$
P C C_{S E_{i j}}=\sqrt{\frac{\left(1-P C C_{i j}^{2}\right)^{2}}{\mathrm{df}_{i j}}}
$$

Note that PCC are statistically rather economically meaningful. This should be kept in mind when interpreting the results.

Turning to explanatory variables, we follow the advices provided by Stanley and Doucouliagos (2012) and focus on five classes to explain heterogeneity.

The data regroup all the variables (or family of variables) that account for data heterogeneity in the primary studies. It concerns the sources, the time period under study (the number of years relative to 1990 precisely) as well as the type of countries (developing/developed) considered.

Econometrics aims at distinguishing the type of data (time-series, cross-section or panel) and the estimators employed (for example OLS or IV). It is particularly relevant for addressing the problems of endogeneity that arise from primary studies. The functional forms of the models (lin-lin, log-lin, log-log) are also listed.

Model specification is necessary to appraise the impact of modeling designs on the study outcomes. It encompasses the (control) variables included in the growth regressions, such as initial income, investment or openness; the dummy variables taking into account specific features (time dummies, characteristic dummies),.$^{7}$ or interaction variables.

Resource measurements tackle the problems discussed in Section 2, raised by the way primary authors measure resources: abundance versus dependence, appropriability. We have identified six mains measures, listed in Section 2.8 Abundance variables consist in all that measure natural wealth (in stock or value terms), while the ones that are scaled by the size of the economy are considered as dependence variables.

Publication is made of three variables assessing the problems in line with publication: bias (with the standard errors of PCCs), replication, and Working-papers. All the variables and their descriptive stastistics are reported in tTables 2 and 3.

\footnotetext{
${ }^{7}$ See Table 8 . The dummy classification is of course debatable, however, it allows for reduced multicollinearity risks.

${ }^{8}$ Export-based variables are divided between exports and "primary exports" — found in Sachs and Warner $(1995,1999,2001)$.
} 
Table 2: Descriptive Statistics of covariates used in the MRA

\begin{tabular}{|c|c|c|c|c|c|c|}
\hline \multicolumn{3}{|l|}{ VARIABLE } & MEAN & StANDARD ERROR & Min & MAX \\
\hline \multicolumn{3}{|c|}{ Partial Correlation Coefficient (PCC) } & -0.05 & 0.25 & -0.80 & 0.69 \\
\hline \multicolumn{3}{|c|}{ Standard Error of PCC (PCC_SE) } & 0.09 & 0.04 & 0.01 & 0.30 \\
\hline \multicolumn{3}{|c|}{ Number of years relative to 1990} & -2.57 & 10 & -53 & 16 \\
\hline & MEASURE: & of Natural Resources (NR) & & FREQUENCY $=1$ & & FREQUENCY $=0$ \\
\hline \multicolumn{2}{|l|}{$\begin{array}{l}\text { Abundance } \\
\text { - DEPENDENCE }\end{array}$} & \multicolumn{2}{|l|}{ Dummy $=0$ if Dependence Measure, 1 if Abundance measure. } & 482 & & 923 \\
\hline \multicolumn{2}{|l|}{ Primary_Exports } & \multicolumn{2}{|l|}{ Dummy $=1$ if NR is expressed as exports over total exports } & 89 & & 1316 \\
\hline \multicolumn{2}{|l|}{$\begin{array}{l}\text { Employment } \\
\text { - ABUNDANCE }\end{array}$} & \multicolumn{2}{|l|}{ Dummy $=1$ if NR is expressed in terms of Employment } & 64 & & 1341 \\
\hline \multicolumn{2}{|l|}{ Natural_Capital } & \multicolumn{2}{|l|}{ Dummy $=1$ if NR is expressed in terms of Natural Capital } & 57 & & 1348 \\
\hline \multirow{2}{*}{\multicolumn{2}{|c|}{$\begin{array}{l}\text { Rents } \\
\text { Reserves }\end{array}$}} & \multicolumn{2}{|l|}{ Dummy $=1$ if NR is expressed in terms of Rents } & 266 & & 1139 \\
\hline & & \multirow{2}{*}{\multicolumn{2}{|c|}{ Dummy $=1$ if NR is expressed in terms of Production }} & 51 & & 1354 \\
\hline \multirow{2}{*}{\multicolumn{2}{|c|}{ Production** }} & & & 221 & & 1184 \\
\hline & & \multicolumn{2}{|l|}{ APPROPRIABILITY } & & & \\
\hline \multicolumn{2}{|l|}{ Point } & \multicolumn{2}{|l|}{ Dummy $=1$ if NR comprises point-source NRs } & 616 & & 789 \\
\hline \multicolumn{2}{|l|}{$\begin{array}{l}\text { Diffuse } \\
\text { - Diffuse }\end{array}$} & \multicolumn{2}{|l|}{ Dummy $=1$ if NR comprises diffuse NRs } & 130 & & 1275 \\
\hline \multicolumn{2}{|l|}{$\begin{array}{l}\text {-DIFFUSE } \\
\text { Agri }\end{array}$} & \multicolumn{2}{|l|}{ Dummy $=1$ if NR Variable includes agricultural NRs } & 95 & & 1310 \\
\hline \multicolumn{2}{|l|}{$\begin{array}{l}\text { Food } \\
\text { - PoINT-Source }\end{array}$} & \multicolumn{2}{|l|}{ Dummy $=1$ if NR Variable includes food NRs } & 94 & & 1311 \\
\hline Fuel & & \multicolumn{2}{|l|}{ Dummy $=1$ if NR Variable includes fuel NRs } & 347 & & 1058 \\
\hline Ore_mineral & & \multicolumn{2}{|l|}{ Dummy $=1$ if NR Variable includes mineral NRs } & 645 & & 1060 \\
\hline Forestry & & \multicolumn{2}{|l|}{ Dummy $=1$ if NR Variable includes forestry } & 41 & & 1364 \\
\hline Subsoil & & \multirow{2}{*}{\multicolumn{2}{|c|}{$\begin{array}{l}\text { Dummy }=1 \text { if NR Variable includes subsoil } \\
\text { Dummy }=1 \text { if NR Variable includes precious metals }\end{array}$}} & 28 & & 1377 \\
\hline Precious met & & & & 5 & & 1370 \\
\hline
\end{tabular}

Notes. **: The Production variable, once scaled by the size of the economy is considered as a Dependence measure. The same applies to the other variables.

\subsection{Econometric features}

Baseline specification A simple meta-regression model would consist in the following:

$$
P C C_{i j}=\alpha_{0}+P C C_{S E_{i j}} \alpha_{1}+X_{i j} \beta+v_{i j}
$$

with $X$ an $L \times K$ matrix of moderator variables $(j=1, \ldots, L$ regressions and $k=1, \ldots, K$ variables), $\beta$ a $K \times 1$ vector of MRA coefficients, and $v_{i j}$ the sampling error of the $i j$-th regression. $P C C_{S E_{i j}}$ is the effect size's standard error which is used to account for potential publication bias as noted in the previous Section. If such an effect exists, then the reported estimate will be positively correlated with its standard error, ceteris paribus.

Weighted Least Squares Unlike conventional econometric models, MRA cannot assume that errors are independently and identically distributed since standard errors of the multiple effect sizes (comprising our database) are most likely to vary from one estimate to the other. Moreover, dependence is likely to arise among reported estimates, especially when multiple estimates from a sole study are coded (Stanley, 2001; Doucouliagos and Stanley, 2012). If a paper has a lot of observations, as it is the case in Boschini et al. (2007) with 310 reported estimates (Table 2), its results might dominate the whole meta-analysis. Estimating MRA with OLS procedures would thus lead to unbiased estimates though they will not be 
Table 3: Descriptive Statistics of covariates used in the MRA (continued)

\begin{tabular}{|c|c|c|c|}
\hline \multicolumn{2}{|r|}{ THE DATA } & FREQUENCY $=1$ & FREQUENCY $=0$ \\
\hline SW & Dummy $=1$ if Data retrieved from Sachs and Warner $(1995,1997)$ & 234 & 1171 \\
\hline Developed & Dummy $=1$ if developped countries are considered & 123 & 1282 \\
\hline Developing & Dummy $=1$ if developing countries are considered & 148 & 1257 \\
\hline \multicolumn{4}{|c|}{ ECONOMETRICS } \\
\hline \multicolumn{4}{|c|}{ —FUnCTIONAL FORM } \\
\hline Lin_lin & Dummy $=1$ if Functional form is Linear-linear & 171 & 1234 \\
\hline $\begin{array}{l}\text { Log_log } \\
\text {-STRUCTURE }\end{array}$ & Dummy $=1$ if Functional form is Log-log & 264 & 1141 \\
\hline Cross & Dummy $=1$ if Structure of data is cross-sectional & 977 & 428 \\
\hline $\begin{array}{l}\text { Time_series } \\
\text {-MEthods }\end{array}$ & Dummy $=1$ if Structure of data is time series & 8 & 1397 \\
\hline Endogeneity & Dummy $=1$ if endogeneity is controlled for (IV or GMM) & 388 & 1017 \\
\hline Meth_others & Dummy $=1$ if estimation technique uses FLIML, CI and SUR & 11 & 1394 \\
\hline \multicolumn{4}{|c|}{ MODEL SPECIFICATION } \\
\hline \multicolumn{4}{|c|}{ — Control Variables } \\
\hline init_income & Dummy $=1$ if Initial Income absent & 274 & 1131 \\
\hline investment & Dummy $=1$ if Investment absent & 460 & 945 \\
\hline openness & Dummy $=1$ if Trade Openness absent & 511 & 894 \\
\hline institutions & Dummy $=1$ if Institutions absent & 544 & 861 \\
\hline human_k & Dummy = 1 if Human Capital included & 372 & 1033 \\
\hline physical_k & Dummy $=1$ if Physical Capital included & 117 & 1288 \\
\hline competitiveness & Dummy $=1$ if Competitiveness included & 245 & 1160 \\
\hline policy & Dummy $=1$ if Policy included & 188 & 1217 \\
\hline $\begin{array}{l}\text { geo } \\
- \text { DUMMIES }\end{array}$ & Dummy $=1$ if Geography included & 7 & 1398 \\
\hline D_events & Dummy $=1$ if Events dummy included, 0 otherwise & 8 & 1397 \\
\hline D_geo & Dummy $=1$ if Geographical dummy included & 618 & 787 \\
\hline D_time & Dummy $=1$ if Time dummy included & 162 & 1243 \\
\hline D_instit & Dummy $=1$ if Institutional dummy included & 88 & 1317 \\
\hline D_political & Dummy $=1$ if Political Regime dummy included & 33 & 1372 \\
\hline D_charact & Dummy $=1$ if Country Characteritics dummy included & 59 & 1346 \\
\hline \multicolumn{4}{|c|}{ - INTERACTION } \\
\hline interact_instit & Dummy $=1$ if (Natural Resource*Institution) Interaction variable included & 479 & 926 \\
\hline interact_others & Dummy $=1$ if (Natural Resource*Others) Interaction variable included & 158 & 1247 \\
\hline Replication & Dummy $=1$ if Regression replicates SW & 14 & 1391 \\
\hline WP & Dummy $=1$ if the estimate comes from a unpublished study & 178 & 1227 \\
\hline
\end{tabular}

consistent. This is why the baseline regression is usullay estimated using weighted-least squares (WLS). Our model to be estimated (WLS-MRA) will be:

$$
\frac{P C C_{i j}}{a_{i j}}=\frac{1}{a_{i j}} \alpha_{0}+\frac{P C C_{S E_{i j}}}{a_{i j}} \alpha_{1}+\frac{1}{a_{i j}} X_{i j} \beta+\frac{1}{a_{i j}} v_{i j}
$$

Unlike least squares, each term in the WLS includes an additional weight $a_{i j}$ that determines how much each observation in the dataset influences the final parameter estimates. While conventional econometricians would generally need the estimated squared residuals to correct for heteroskedasticity, we already have the required variance to compute analytical weights, which corresponds to the variance of the PCC as defined in (2) 9

\footnotetext{
${ }^{9}$ We could use the standard error of the PCC as analytical weights but most statistical software calculates the WLS version of (4) with each estimates' variance (Doucouliagos and Stanley, 2012).
} 
An important feature of this model is that the original constant term, which represents the "true" underlying empirical effect can now be recovered from $\alpha_{1}$, while $\alpha_{0}$ takes the precision of the effect in regression $i j{ }^{10}$ Re-writing Equation (4), we get:

$$
P \tilde{C}_{i j}=\alpha_{1}+\alpha_{0} P R E C_{i j}+\tilde{X}_{i j} \beta+\tilde{v}_{i j}
$$

with $\sim$ indicating the transformed variables and $P R E C_{i j}$ the inverse of the estimates' standard error (Equation (2)).

As stated by Stanley and Doucouliagos (2012), MRA can be improved by considering (un)balanced panel data models. Indeed these techniques are specially designed to address the problem of dependence between observations (which is the case in meta-analysis when primary studies report more than one estimate). By adding a study-level component in the error-term structure, one can account for influencial common unreported or unobserved factors. There are two ways for modelling these factors: the fixed effects model and the random effects model.

The Fixed effects model amounts to include an individual dummy for each study of the panel in order to account for those study specific characteristics that have been forgotten in the moderators or that are unobservable:

$$
P \widetilde{C} C_{i j}=\alpha_{1}+\alpha_{0} P R E C_{i j}+\tilde{X}_{i j} \beta+\sum_{j=1}^{L} \delta_{i} \tilde{D}_{i j}+\tilde{\epsilon}_{i j}
$$

with $L$ dummy variables $\left(D_{i j}\right)$ assuming we omitted the intercept. This Least Square Dummy Variable approach allows us to use the inverse of the standard errors' effect sizes as analytic weights (Stanley and Doucouliagos, 2012). Equation (6) is hence usually labeled Fixed-effect WLS.

The Random effects model amounts to include a random term because unexplained heterogeneity is supposed to come from a population effect (underlying population differences). The model can be written as :

$$
P \widetilde{C} C_{i j}=\alpha_{1}+\alpha_{0} P R E C_{i j}+\tilde{X}_{i j} \beta+\tilde{u}_{j}+\tilde{u}_{i j}
$$

where $\tilde{u}_{j}$ is the random term. Equation 7 is usually labeled Mixed-effect WLS since it contains moderators and is weighted by standard errors of effect-sizes. Note that Mixed-effect WLS assume that moderators $\tilde{X}_{i j}$ are independent from $\tilde{v}_{j}$. This is rarely the case in MRA,

\footnotetext{
${ }^{10}$ If each variable is weighted and regression (4) estimated using OLS, then we need to be careful when interpreting the supposedly constant term. It will refer to precision. However, if we, for instance, estimate the regression on non-transformed variables simply adding an " $\left[\right.$ aweight $\left.=P C C_{-} V A R \_P R E C\right]$ " in the computer program, then the intercept will correspond to the "true" underlying effect size.
} 
leading to biased results. Hence Mixed-effect WLS have to be used with caution (see Stanley and Doucouliagos (2012) for further explanations on bias and the use of Mixed-effects WLS). Moreover, as additional insurance we follow Stanley and Doucouliagos (2012), by clustering standard-errors at the study level in all specifications, in order to make them robust to intrastudy dependence. This does not affect the estimated coefficients, only their significativity in a more conservative way.

Finally, we pay a special attention to multicollinearity in our regressions. To our knowledge, little attention has been provided to this topic in the MRA literature, despite being a major caveat. The effects of multicollinearity are well-know in "traditional" econometrics: (i) parameters (both coefficients and standard errors) are unstable and hence sensitive to little changes in observations or to the inclusion (exclusion) of a new variable, (ii) the impact of explanatories on the dependent are impossible to disentangle, and (iii) despite the nonsignificance of explanatories, coefficients of determination are high. In other words, estimates are far from robust. MRA is even more subject to multicollinearity than "traditional" econometrics since almost all the explanatories are dummy variables. In order to avoid the problem, we rely on Variance Inflation Factors (VIF), and apply a simple rule of thumb: all variables have to present a VIF near or above 10, and the mean VIF must be around 5 .

\section{Results and Interpretation}

The results of the MRA are reported throughout Tables 4 and $5 \mathbb{1 1}^{11}$ In Table 4 , we investigate whether the way natural resources are measured changes the outcome of the commonly found resource curse, i.e. whether using abundant-based resource variables have an impact or not. We first differentiate resources that translate wealth from those that embed dependence or intensity (Columns (2)-(4)) and then introduce dummies that account for the six measures the most used in the literature, namely employment, primary exports, natural capital, rents, reserves and production. Our aim is also to assess the validity of the appropriability hypothesis, advocated in the literature. Table 5 reports two different regressions that aim at testing whether the appropriability hypothesis holds. The first one includes a point dummy for studies whose natural resources variable accounts for either fuel, ore and minerals and precious metals, and a diffuse dummy when food or agricultural commodities are considered. The omitted variable regroups measures that incorporate all types of resources such as a primary exports-to-GDP ratio for example. The second specification includes disaggregated dummies of natural resources measures. The natural component is divided in seven groups that are: agricultural, food, fuel, ores and mineral, forestry, subsoil and precious metals.

Before turning to specific interpretation, there are findings that are noteworthy and systematic, regardless of the table we consider ${ }^{12}$ First, what may be drawn from the empirical

\footnotetext{
${ }^{11}$ As a robustness check, we performed the same MRA but included disaggregated institutional variables and dropped the variable "institution". Results remain the same, illustrating the robustness of our findings, and are available upon request to the authors.

${ }^{12}$ The Fixed effects (FE) model - Columns (2)-(5) - is the preferred model as it allows to account for
} 
literature is that the average effect of natural resources on economic growth favors the existence of the resource curse. Indeed, the meta-average (constant term) varies from -0.100 to -0.182 and is significant most of the time at the $1 \%$ confidence level. According to Doucouliagos' guidelines on the size of PCC (2011), one can argue that the effect is small to medium, indicating a kind of "soft" curse. One should note that all the other parameters require an interpretation with respect to this constant term. In addition, there is no sign of publication bias since PCC_SE never enters significantly the regressions.

Among the common sources (Section 2.2 that may explain heterogeneity in the literature, the research design is an important feature. Cross-sectional datasets result in larger negative resource-growth effects than the use of panel data. The use of Sachs and Warner's dataset results in an increased resource-growth effect that is negative. Control for endogeneity either by the IV or the GMM methods allows for a smaller effect size of the resource curse, though it appears only in the WLS estimation and it is significant at the $10 \%$ confidence level. Estimating a growth regression in a log-log framework strongly helps reversing the resource curse, ceteris paribus, compared to a log-lin specification (the omitted variable). The coefficient associated with developed countries is positive and statistically significant; hence studies that include developed countries in their sample are more likely to find a mitigated resource curse effect than those considering all types of countries, though the estimated effect size remains negative. This is a very interesting result since it tends to support that the level of development plays a role in the intensity of the curse/blessing. This idea has already been developed towards literature through the lens of institutional quality (North et al., 2007). Another source of heterogeneity may arise from the control variables that are included or not in the growth equations. Not including initial income may result in a smaller resource curse estimate biased downwards. Indeed, one should keep in mind that not allowing for economic convergence in growth equations may lead to omitted variable bias, especially in cross-sectional settings (Arezki and van der Ploeg, 2007). Finally, accounting for geographical features (both through dummy and control variables) seems to reduce the most strongly the negative association between natural resources and economic growth, while policy and human capital variables' inclusion in growth equations only allows for a small diminution of the resource curse and significantly mostly at the $10 \%$ confidence level. The literature acknowledges the importance of institutional quality in the resource curse though when the variable is dropped, the detrimental effect of natural resources on growth remains the same, regardless of whether one considers Institutions or Natural resources $\times$ Institutions. Hence, including a proxy for the institutional framework does not seem impact directly the results. We will deepen the question in Section 5.

Turning to the source of heterogeneity evoked in Section 2.2, considering a variable expressing resource wealth and a one that translates the intensity of dependence on such wealth

unobserved heterogeneity whereas the Weighted Least Squares (WLS) do not. In addition, it takes care of potential dependence among estimates from a given study. Finally, FE estimators are close to the RE ones, i.e. heterogeneity is due to the research design rather than because of random factors: the FE model is preferred (Hunter and Schmidt, 2004), insomuch as RE may provide bias results (recall previous section). 
cannot lead to the same implications in terms of the resource curse. Abundance measures do not seem to significantly mitigate the resource curse (Equation (1)-(3)). Although coefficients are low, they are not significant. This means that distinguishing between abundance and dependence measures only may not be sufficient to explain the differences in the effect sizes found in the literature. In order to check whether a more in-depth disaggregation between resource measurements helps better understand heterogeneity, we focus on the 6 natural resource measures with Exports_GDP being the reference (the omitted variable). All in all, using exports of resources over total exports gives rise to a deeper resource curse than if the exports-to-GDP were considered. The more the countries depend on their exports of resources, the more likely they are to experience a decline in growth. However, this result only holds in Equation (1), overall Primary_Exports behaves quite similarly as Exports_GDP. Considering employment-based or reserves-based measures leads to the same outcome, the negative association is mitigated and to some extent reversed into a positive one, though only in Equation (1). Natural capital is the most significant variable out of the ones generally used in the literature. This variable reflects the most abundance and tends to be associated with a resource blessing, as it is usually found in the literature (Gylfason, 2001; Gylfason and Zoega, 2006; Brunnschweiler, 2008; Brunnschweiler and Bulte, 2008; Cruzten and Holton, 2011). The effect switches from -0.125 when exports-to-GDP is accounted for to 0.117 once natural capital is considered (Equation (2a)) ${ }^{13}$ ceteris paribus. Rents tend to result in a more detrimental effect on growth even though the coefficient is very small.

Another source of heterogeneity that was previously mentioned is the differentiation of the appropriability aspects of resources. The more appropriable the resources, the more difficult it seems to be to make the most of it. In the first three columns of Table 5 , both point and diffuse dummies are significant (at the $10 \%$ and $5 \%$ confidence level, respectively). Both indicate that considering point or diffuse variables allows finding a reduced resource curse, though small (0.01 and 0.03, respectively). Studies that account for more agricultural and food resources measures find on average a smaller effect size compared to the ones that use an aggregated measure or a point source-based variable. However, there is poor evidence of particular pattern in terms of appropriabilty. This may be due, to some extent, to the fact that the omitted variable that incorporates all resource types does not allow to distinguish the share of both point-source and diffuse resources, respectively. The last three columns depict the results with the disaggregated resource-type measures. Food resources are not found to play a significantly different role to that of an all resource-type measure. In addition, the consideration of agricultural and forestry resources reduces the link between natural resources and growth, on a small basis only (0.05 and 0.02 , respectively). Surprisingly, the same result is found for fuel minerals although their extraction may give high intensives for rent-grabber friendly behaviors and economic consequences thereof. Ores and minerals are positively related to the resource curse, considering these types of resources increases the effect size and thus the resource curse, ceteris paribus. Subsoil measures are associated

\footnotetext{
${ }^{13}$ Equation (2a) differs from Equation (2) with respect to the resource variables that are considered. While Equation (2) discriminates between abundance and dependance measures, Equation (2a) discerns the six ways natural resource variables are expressed in the literature.
} 
significantly and positively to the effect size, they are even associated as a small blessing since the final effect if positive $(-0.140+0.206=0.66$, cf. Eq 2a). These results are somewhat counter-intuitive since subsoil measure incorporates resources that are most likely to be extracted and hence, to rent-seeking incentives.

Finally, results do seem to reveal a particular pattern with respect to the appropriability hypothesis. We previously evidenced that the literature emphasized the close ties between resources and the quality of institutions, especially by using interaction variables in growth equation. If the direct effect is not large, there might be answers to find from the study of the indirect effect size.

\section{On the specific role of institutions}

As we emphasized in the former section, results are not clear-cut, and somewhat counterintuitive relative to "appropriability". This may be due to the way institutions are accounted for. Indeed the "appropriability" hypothesis is entangled with the nature and mostly the quality of institutions. A way to shed some light on the topic, and obtain more reliable results is to pay interest on the effects of natural resources on growth when the former are conditioned by institutions. It is possible with our panel studies through a specific MRA on the coefficients of interaction terms (Natural Resources $\times$ Institutions). Despite the restrictions it imposes, we dispose of 176 estimates ${ }^{14}$ distributed among 17 studies.

\subsection{The variables}

When focusing on interaction terms, the dependent variable is not straightforward: the marginal effect under study is not reflected by the coefficient of the interacted variables, but by the coefficient multiplied by the conditioning variable (Stanley and Doucouliagos, 2012). Say that Equation $(8)$ is the growth model of a primary study containing an interaction term between Natural Resources and Institutions:

$$
Y=\beta_{0}+\beta_{1} N R \times I+\sum_{i=2}^{k} \beta_{k} X_{k}+\epsilon
$$

where $Y$ is growth, $N R$ the conditioned variable (natural resource) and $I$ the conditioning variable (institutions). When regarding the marginal effect, we get:

$$
\frac{\partial Y}{\partial \mathrm{NR}}=\beta_{1} I
$$

IAs a consequence, when studies do not directly report marginal effects (as in our case), it is impossible to implement a meta-regression, unless the conditioning variable is bounded.

\footnotetext{
${ }^{14}$ Initially, there were 430 estimates, among which 290 were retrieved from Boschini et al. (2013). This raised the problem of over-representation of this specific study and the bias it could thus introduce. We decided to only keep the results that authors considered as the bests (overall 36).
} 
One can then fix an arbitrary value inside the bounds and interpret results relative to the chosen value. It is precisely the methodology we adopt since all measures of institutions are bounded. We first rescale them in order to obtain the lower bound at 0 (lowest institutional quality) and the upper bound at 1 (best institutional quality), and hence choose to fix institutional quality at 1 so that the marginal effect is equivalent to the estimated coefficient of the interacted variables. As in Section 4 , we transform the estimated coefficients into PCCs because of functional form problems, and also derive the standard errors.

Since the sample at our disposal for interaction terms is highly restricted relative to that of Section 4, the degrees of freedom problem raised in Section 3.2 is even more accurate. It forces us to focus on limited sources of heterogeneity (here we are mainly interested by "appropriability" and institution measures), which leads us to build a new set of explanatory variables. Comparing to Section 4, there is no change regarding the data group, nor the publication group other than replication which is dropped since there are no replicated results. The category econometrics is redesigned, since family variables are recoded into dummy variables. Hence we are only able to account for the control of endogeneity, panel frameworks and double-log functional forms. Resource measurements now only handle the "appropriability" feature, and we decide to relinquish the category model specification (since it may be partially handled by fixed-effects) in favor of a family variable allowing us to distinguish the institution variables of the primary literature. The descriptive statistics are reported in Table 6 .

\subsection{Results}

Results are reported in Table 7. On the left-hand side a general specification regarding "appropriability" is adopted thanks to point and diffuse, while the right-hand side is attached to disegreggate "appropriability" at the sectoral level. As previously, three different estimators are used: WLS, WLS-FE and WLS-MIXED. Again, our preferred outcome is from the WLS-FE, because when compared to WLS its errors structure allows to account for a greater part of heterogeneity, though it does not suffer from bias as WLS-MIXED.

The first remark when looking at the results is that once corrected from the fixed-effects, the meta-average (constant) becomes significant and the publication bias (PCC_SE) disappears in the two specifications (Equations (2) and (2a)). It indicates that, when institutional quality is at its best 15 there seems to be a positive and significant link between natural resources and growth. In other words, and taking stock from literature, institutional quality seems to play an indirect role in mitigating the curse we found in the precedent section. Moreover, based on the guidelines provided by Doucouliagos (2011), we can consider the value of the meta-average (between 0.328 and 0.343 ) as medium to large.

Regarding general sources of heterogeneity, the usual suspects are round up. All the vari-

\footnotetext{
${ }^{15}$ Recall that PCCs have been calculated on the basis that Institutional Quality takes 1, which is the upper bound of the variable.
} 
ables reflecting differences in econometric characteristics are significant in the fixed-effect estimates. Thus, studies that adopt panels rather than cross-section specifications find smaller effects between natural resources and growth (around -0.1), as for those accounting for endogeneity (around -0.13), and just as well as those using double log functional form (-0.97). Among the data, neither the time period nor the type of countries are at work. However, using the data of Sachs and Warner clearly leads to lower the results (by approximatively $0.41 / 0.35)$.

When paying attention to the specific categories of heterogeneity, a very interesting pattern emerges that is able to address the question of "appropriability". First of all, if the way institutional quality is measured plays a role when looking at WLS outcome, once fixed-effects are controlled for, only government effectiveness (in Equations (2) and (2a)) and rule of law (in Equation (2a)) have a different behavior relative to ICRG institutional quality measure (our omitted variable).

Turning to the measure of natural resources, it comes at first glance that coefficients are wrongly-signed, invalidating the appropriability hypothesis. Hard-to-appropriate resources enter negatively (diffuse in Equation (2), and agriculture, food, forestry in Equation (2a)), while easy-to-appropriate resources enter, on the whole, positively (ores and minerals, subsoil in Equation (2a), point in Equation (2) despite non-significant), suggesting that hardto-appropriate are a curse when easy-to-appropriate are a blessing. To fully understand the scope of these results that go against the literature, one has to remember that these latter have to be interpreted relatively i) to the omitted variable that is all types of natural resources (point and diffuse), and ii) to the fact that institutional quality is fixed as its best. It then comes that when institutional framework is perfect (no rent-seeking is possible), the relation between natural resources and growth is stronger when the country has point resources at its disposal than a mix of point and diffuse; and that the relation between natural resources and growth is smaller when natural resources are composed by diffuse rather than a mix of point and diffuse. This is supported by the fact that point are usually more profitable than diffuse resources (Brunnscwheiler and Bulte, 2008). Therefore, when institutions ensure the better allocation, point are thought to be more growth enhancing than diffuse resources.

On the whole, our results seem to confirm the view that the question of resource "appropriability" together with the shape of institutions is crucial when determining if natural resources are a curse or a blessing. Nonetheless, we are not able to settle the problem here, since these results do not reflect the direct outcome of natural resources on growth, but only the partial effects, calculated with the highest institutional quality.

\section{Conclusion}

In this paper, we review a large body of literature that is devoted to the paradox of plenty. So far, results on the topic are highly controversial and the impact of natural resources on growth 
seems to depend on a few identified factors, namely the way resources are measured, the type of resources considered, and finally the institutional framework of resource-rich countries. To address the problem, we implemented two distinct meta-regressions: one on the direct effects of natural resources on growth, and another on the indirect effects, namely the impact of natural resources on growth when controlling for the quality of institutions. Relying on 67 primary studies, our aim is twofold: both quantify the magnitude of curse/blessing and identify the sources of heterogeneity, as well as confront our results to the previous literature.

We put forward that there seems to be a "soft" resource curse in literature. Indeed, the statistical link (partial correlation coefficient) between resources and growth lies between -0.1 and -0.182, which is, according to the guidelines of Doucouliagos (2011), quite small. Moreover, these results are immune to publication bias, as we find no evidence of it. A few sources of heterogeneity may be pointed out, such as the control variables included in the primary models, the econometric methods, or the sample under study. Contrary to conventional wisdom, institutions play no significant role. Furthermore, the most important feature is decidedly the measure of resources that is able to reverse a "soft" curse into a "soft" blessing, particularly when considering measures that traduce abundance rather dependence such as natural capital. When considering the type of resources, there is no clear pattern that hard-to-grab resources impact growth differently from the easy ones. Yet we do not immediately interpret this finding as a rejection of the "appropriability" hypothesis and rather prefer to explore the links appropriability may nourish with institutional quality.

We show that the interaction between the type of resources and the quality of institutions is crucial for growth. We find evidence that when institutional quality is at its best, there is a positive and statistically significant link between resources and growth that lies around 0.33, which can be considered as quite important. We also find, in this high-quality institutional framework that point-source are more beneficial for growth than diffuse resources, supporting the "appropriability" hypothesis.

However, one may be cautious with the outcome of the second meta-regression. Indeed, it does only reflect a partial and indirect effect of natural resources on growth (that with the higher institutional quality) and it cannot directly be merged with the results of the first meta-regression. In other words, we are only able to draw that the quality of institutions may mitigate the resource curse, not that it can reverse it into a blessing.

On the whole our results supports the view that the resource curse exists but it is moderate and dependent on study characteristics, such as the type of country (developing/developed) and the measure of natural resource (abundance/dependence) considered. We also validate the fact that "appropriablity" is a real concern regarding the paradox of plenty, and that institutions are definitely a mitigating factor of the resource curse. 


\section{References}

Acemoglu, D., \& Robinson, J. A. Persistence of Power, Elites, and Institutions. The American Economic Review, 2008, pp. 267-293.

Acemoglu, D., Robinson, J. A., \& Verdier, T. Alfred Marshall Lecture: Kleptocracy and Divide-and-Rule: A Model of Personal Rule. Journal of the European Economic Association, 2004, pp. 162-192.

Aghion, P., Bacchetta, P., Ranciere, R., \& Rogoff, K. Exchange rate volatility and productivity growth: The role of financial development. Journal of Monetary Economics, 56(4), 2009, pp. 494-513.

Ahmadov, A. K. Oil, Democracy, and Context A Meta-Analysis. Comparative Political Studies, 47(9), 2014, 1238-1267.

Baxter, M., \& Kouparitsas, M. A. What Can Account for Fluctuations in the Terms of Trade?. International Finance, 9(1), 2006, pp. 63-86.

Barro, R. J. Economic Growth in a cross-section of countries. Quarterly Journal of Economics, 1991, 106(2), pp. 407-443.

Beck, T. Finance and Oil: Is there a resource curse in financial development?. European Banking Center Discussion Paper, 004, 2011.

Benos, N., \& Zotou, S. Education and economic growth: A meta-regression analysis. World Development, 64, 2014, pp. 669-689.

Caselli, F., \& Michaels, G. Do oil windfalls improve living standards? Evidence from Brazil (No. w15550). National Bureau of Economic Research, 2009.

Corden, W. M., \& Neary, J. P. Booming sector and de-industrialisation in a small open economy. The Economic Journal, 1982, pp. 825-848.

Deacon, R. T. The Political Economy of the Natural Resource Curse: A Survey of Theory and Evidence. Foundations and Trends (R) in Microeconomics, 7(2), 2011, pp. 111208.

Deacon, R. T., \& Rode, A. Rent seeking and the resource curse. Companion to the Political Economy of Rent Seeking, 227(14), 2015.

De Long, J. B., \& Summers, L. H. How strongly do developing economies benefit from equipment investment?. Journal of Monetary Economics, 32(3), 1993, pp. 395-415.

Doucouliagos, H. How large is large? Preliminary and relative guidelines for interpreting partial correlation is economics. School of accounting, economics and finance. Deakin University, 2011. 
Doucouliagos, H., \& Stanley, T. D. Publication Selection Bias in Minimum-Wage Research? A Meta-Regression Analysis. British Journal of Industrial Relations, 47(2), 2009, pp. 406-428.

Glass, G.V., McGaw, B., Smith, M.L. Meta-analysis In social research. Sage publications. 1981

Gelb, A. H. Oil windfalls: Blessing or curse?. Oxford University Press. 1988

Havranek, T., Horvath, R., \& Zeylanov, A. Natural Resources and Economic Growth: A Meta-Analysis. Czech National Bank and Charles University, Prague, 2015. Available at meta-analysis.cz/resource_curse.

Hodler, R. The curse of natural resources in fractionalized countries. European Economic Review, 50(6), 2006, pp. 1367-1386.

Iwasaki, I., \& Tokunaga, M. Macroeconomic impacts of FDI in transition economies: a meta-analysis. World Development, 61, 2014, pp. 53-69.

Karl, T. L. The paradox of plenty: Oil booms and petro-states (Vol. 26). Univ of California Press, 1997.

King, R. G., \& Levine, R. Finance, entrepreneurship and growth. Journal of Monetary Economics, 32(3), 1993, pp. 513-542.

Knack, S., \& Keefer, P. Institutions And Economic Performance: Cross-Country Tests Using Alternative Institutional Measures. Economics and Politics, 7(3), 1995, 207227.

Lane, P. R., \& Tornell, A. Power, growth, and the voracity effect. Journal of Economic Growth, 1(2), 1996, pp. 213-241.

North, D. C. Institutions and economic growth: an historical introduction. World development, 17(9), 1989, pp. 1319-1332.

North, D. C., Wallis, J. J., Webb, S. B., \& Weingast, B. R. Limited Access orders in the Developing World: A New Approach to the Problems of Development. Policy Research Working Paper Series, 4359, The World Bank, Washington D.C., 2007.

Pearson, K. Mathematical contributions to the theory of evolution (Vol. 13). Dulau and co., 1904.

Pindyck, R. S. The optimal exploration and production of nonrenewable resources. The Journal of Political Economy, 1978, pp. 841-861.

van der Ploeg, F. Natural resources: Curse or blessing?. Journal of Economic Literature, 2011, pp. 366-420. 
Ross, M. L. Does oil hinder democracy?. World Politics, 53(03), 2001, pp. 325-361.

Rothstein, H. R., Sutton, A. J., \& Borenstein, M. (Eds.) Publication Bias in Meta-Analysis: Prevention, Assessment and Adjustments. John Wiley \& Sons. 2006

Stanley, T. D. Wheat from chaff: Meta-analysis as quantitative literature review. Journal of Economic Perspectives, 2001, pp. 131-150.

Stanley, T. D., \& Doucouliagos, H. Meta-regression Analysis in Economics and Business. Volume 5, Ed. Routledge, 2012.

Stanley, T. D., \& Jarrell, S. B. Meta-Regression analysis: A quantitative method of literature surveys. Journal of Economic Surveys, 3(2), 1989, pp. 161-170.

Tornell, A., \& Lane, P. R. The voracity effect. The American Economic Review, 1999, pp. $22-46$.

Torvik, R. Natural resources, rent seeking and welfare. Journal of Development economics, 67(2), 2002, pp. 455-470.

Wolf, C. Institutions and economic development. American Economic Review, 1955, pp. 867-883.

\section{A Sample}

1. Alexeev, M. and Conrad, R. The elusive curse of oil. The Review of Economics and Statistics, 2009, vol. 91, no 3, p. 586-598.

2. Alexeev, M. and Conrad, R. The natural resource curse and economic transition. Economic Systems, 2011, vol. 35, no 4, p. $445-461$.

3. Alkhater, K. R. The Rentier Predatory State Hypothesis: An Empirical Explanation of the Resource Curse. Journal of Economic Development, 2012, vol. 37, no 4, p. 29.

4. Andersen, J. J. and Aslaksen, S.. Constitutions and the resource curse. Journal of Development Economics, 2008 , vol. 87, no 2, p. 227-246.

5. Arezki, R. and van der Ploeg, F. Can The Natural Resource Curse Be Turned Into A Blessing? The Role of Trade Policies and Institutions. Oxford Centre for the Analysis of Resource Rich Economies, University of Oxford, 2008.

6. Atkinson, G. and Hamilton, K. Savings, growth and the resource curse hypothesis. World Development, 2003, vol. 31, no 11 , p. $1793-1807$.

7. Baggio, J. A. and Papyrakis, E. Ethnic diversity, property rights, and natural resources. The Developing Economies, 2010, vol. 48, no 4, p. 473-495.

8. Behbudi, D., Mamipour, S. and Karami, A. Natural resource abundance, human capital and economic growth in the petroleum exporting countries. Journal of Economic Development, 2010, vol. 35, no 3, p. 81.

9. Bjorvatn, K., Farzanegan, M. R. and Schneider, F. Resource curse and power balance: evidence from oil-rich countries. World Development, 2012, vol. 40, no 7, p. 1308-1316.

10. Bjorvatn, K. and Farzanegan, M. R. Demographic transition in resource rich countries: a blessing or a curse?. World Development, 2013, vol. 45, p. 337-351.

11. Boschini, A. D., Pettersson, J. and Roine, J. Resource Curse or Not: A Question of Appropriability. The Scandinavian Journal of Economics, 2007, vol. 109, no 3, p. 593-617.

12. Boschini, A. D., Pettersson, J. and Roine, J. The resource curse and its potential reversal. World Development, 2013, vol. 43, p. 19-41.

13. Boyce, J. R. and Emery, J. H. Is a negative correlation between resource abundance and growth sufficient evidence that there is a "resource curse"?. Resources Policy, 2011, vol. 36, no 1, p. 1-13. 
14. De Grégorio, J. and Bravo-Ortega, C. The relative richness of the poor? natural resources, human capital, and economic growth. Policy Research Working Paper Series 3484, The World Bank, 2005.

15. Brückner, M. Natural resource dependence, non-tradables, and economic growth. Journal of Comparative Economics, 2010, vol. 38 , no 4, p. 461-471.

16. Brunnschweiler, C. N. and Bulte, E. H. The resource curse revisited and revised: A tale of paradoxes and red herrings. Journal of environmental economics and management, 2008, vol. 55, no 3, p. 248-264.

17. Brunnschweiler, C. N. Cursing the blessings? Natural resource abundance, institutions, and economic growth. World development, 2008, vol. 36, no 3, p. 399-419.

18. Corrigan, C. C. Breaking the resource curse: Transparency in the natural resource sector and the extractive industries transparency initiative. Resources Policy, 2014, vol. 40, p. 17-30.

19. Costantini, V., and Monni, S. Environment, human development and economic growth. Ecological Economics, 2008, 64(4), p. 867-880.

20. Cotet, A. M. and Tsui, K. K. Oil, Growth, and Health: What Does the Cross-Country Evidence Really Show?. The Scandinavian Journal of Economics, 2013, vol. 115, no 4, p. 1107-1137.

21. Crutzen, B. S., and Holton, S. The More the Merrier? Natural Resource Fragmentation and the Wealth of Nations. Kyklos, 2011, 64(4), p. 500-515.

22. Davis, G. A. Replicating Sachs and Warner's working papers on the resource curse. Journal of Development Studies, 2013, vol. 49, no 12, p. 1615-1630.

23. Ding, N., and Field, B. C. Natural Resource Abundance and Economic Growths. Land Economics, 2005 81(4), p. 496-502.

24. Douglas, S. M., and Walker, A. Coal Mining and the Resource Curse in the Eastern United States, Department of Economics, West Virginia University, 2014, no 14-01

25. Egert, B. Dutch Disease in the post-soviet countries of Central and South-West Asia: How contagious is it?. Journal of Asian Economics, 2012, vol. 23, no 5, p. 571-584.

26. El Anshasy, A. A. and Katsaiti, M.-S. Natural resources and fiscal performance: Does good governance matter?. Journal of Macroeconomics, 2013, vol. 37, p. 285-298.

27. Fan, R., Fang, Y. and Park, S. Y. Resource abundance and economic growth in China. China Economic Review, 2012, vol. 23 , no 3, p. 704-719.

28. Farhadi, M., Islam, Md. R. and Moslehi, S. Economic Freedom and Productivity Growth in Resource-rich Economies. World Development, 2015, vol. 72, p. 109-126.

29. Freeman, D. G. The "Resource Curse" and regional US development. Applied Economics Letters, 2009, vol. 16, no 5, p. $527-530$.

30. Greasley, D. and Madsen, J. B. Curse and Boon: Natural Resources and Long-Run Growth in Currently Rich Economies. Economic Record, 2010, vol. 86, no 274, p. 311-328.

31. Gylfason, T. Exports, inflation and growth. World Development, 1999, vol. 27, no 6, p. 1031-1057.

32. Gylfason, T. Natural resources, education, and economic development. European economic review, 2001, vol. 45, no 4, p. $847-859$.

33. Gylfason, T. and Zoega, G. Natural resources and economic growth: The role of investment. The World Economy, 2006, vol. 29, no 8, p. 1091-1115.

34. Iimi A. Escaping from the Resource Curse: Evidence from Botswana and the Rest of the World. IMF Staff Papers, 2007, vol. 54, no 4 .

35. Isham, J., Woolcock, M., Pritchett, L. and Busby, G. The varieties of resource experience: natural resource export structures and the political economy of economic growth. The World Bank Economic Review, 2005, vol. 19, no 2, p. 141-174.

36. James, A., and Aadland, D. The curse of natural resources: An empirical investigation of US counties. Resource and Energy Economics, 2011, 33(2), p. 440-453.

37. James, A. G., and James, R. G. Do resource dependent regions grow slower than they should?. Economics Letters, 2011, vol. 111, no 3, p. 194-196.

38. James, A. The resource curse: A statistical mirage?. Journal of Development Economics, 2015, vol. 114, p. 55-63.

39. Ji, K., Magnus, J. R. and Wang, W. Natural resources, institutional quality, and economic growth in China. Environmental and Resource Economics, 2014, vol. 57, no 3, p. 323-343.

40. Kolstad, I. The resource curse: Which institutions matter?. Applied Economics Letters, 2009, vol. 16, no 4, p. 439-442.

41. Konte, M. A curse or a blessing? Natural resources in a multiple growth regimes analysis. Applied Economics, 2013, vol. 45, no 26 , p. 3760-3769. 
42. Kronenberg, T. The curse of natural resources in the transition economies. Economics of transition, 2004, vol. 12, no 3, p. 399-426.

43. Kropf, A. Resource abundance vs. resource dependence in cross-country growth regressions. OPEC Energy Review, 2010, vol. 34, no 2, p. 107-130.

44. Lederman, D. and Maloney, W. F. Trade structure and growth. World Bank Policy Research Working Paper, 2003, no 3025 .

45. Libman, A. Natural resources and sub-national economic performance: Does sub-national democracy matter?. Energy economics, 2013, 37, p. 82-99.

46. Manzano, O. and Rigobon, R. Resource Curse or Debt Overhang?. NBER Working Paper, 2001, no w8390.

47. Mehlum, H. Moene, K. and Torvik, R. Institutions and the resource curse. The economic journal, 2006, vol. 116, no 508, p. $1-20$.

48. Murshed, S. M. and Serino, L. A. The pattern of specialization and economic growth: The resource curse hypothesis revisited. Structural Change and Economic Dynamics, 2011, vol. 22, no 2, p. 151-161.

49. Neumayer, E. Does the "resource curse" hold for growth in genuine income as well?. World Development, 2004, vol. 32, no 10, p. 1627-1640.

50. Norman, C. S. Rule of law and the resource curse: abundance versus intensity. Environmental and Resource Economics, 2009, vol. 43, no 2, p. 183-207.

51. Norrbin, S. C., Pipatchaipoom, O. and Bors L. How robust is the natural resource curse?. International Economic Journal, 2008, vol. 22, no 2, p. 187-200.

52. Oskenbayev, Y. and Karimov, A. Is Kazakhstan vulnerable to natural resource curse?. WIDER Working Paper, 2013.

53. Papyrakis, E., and Gerlagh, R. Resource windfalls, investment, and long-term income. Resources policy, 2006, 31(2), p. $117-128$.

54. Papyrakis, E. and Gerlagh, R. Resource abundance and economic growth in the United States. European Economic Review, 2007, vol. 51, no 4, p. 1011-1039.

55. van der Ploeg, F. and Poelhekke, S. Volatility and the natural resource curse. Oxford economic papers, $2009,27$.

56. Van der Ploeg, F., and Poelhekke, S. The pungent smell of "red herrings": Subsoil assets, rents, volatility and the resource curse. Journal of Environmental Economics and Management, 2010, 60(1), p. 44-55.

57. Al Rawashdeh, R. and Maxwell, P. Jordan, minerals extraction and the resource curse. Resources Policy, 2013, vol. 38, no 2, p. 103-112.

58. Sachs, J. D. and Warner, A. M. Natural resource abundance and economic growth. National Bureau of Economic Research, 1995, No. w5398.

59. Sachs, J. D. and Warner, A. M. Natural resource abundance and economic growth. 1997.

60. Sachs, J. D. and Warner, A. M. The big push, natural resource booms and growth. Journal of development economics, 1999, vol. 59, no 1, p. 43-76.

61. Sachs, J. D. and Warner, A. M. The curse of natural resources. European economic review, 2001, vol. 45, no 4, p. $827-838$.

62. Sala-i-Martin, X. and Subramanian, A. Addressing the natural resource curse: an illustration from Nigeria. Journal of African Economies, 2013, vol. 22, no 4, p. 570-615.

63. Sarr, M., Bulte, E., Meissner, C. and Swanson, T. On the looting of nations. Public Choice, 2011, vol. 148, no 3-4, p. 353-380.

64. Satti, S. L., Farooq, A., Loganathan, N. and Shahbaz, M. Empirical evidence on the resource curse hypothesis in oil abundant economy. Economic Modelling, 2014, vol. 42, p. 421-429.

65. Williams, A. Shining a light on the resource curse: An empirical analysis of the relationship between natural resources, transparency, and economic growth. World Development, 2011, vol. 39, no 4, p. 490-505.

66. Yang, B. Resource curse: the role of institutions versus policies. Applied Economics Letters, 2010, vol. 17, no 1, p. 61-66.

67. Zhang, X., Xing L., Fan, S. and Luo, X. Resource abundance and regional development in China. Economics of Transition, 2008, vol. 16, no 1, p. 7-29. 
Table 4: Results - Resources measurement

\begin{tabular}{|c|c|c|c|c|c|c|}
\hline \multirow[b]{2}{*}{ VARIABLES } & \multicolumn{3}{|c|}{ ABUndanCE VS. DEPENDENCE } & \multicolumn{3}{|c|}{ DETAILED RESOURCES } \\
\hline & WLS Eq. 1 & W-FE Eq. 2 & W-RE Eq. 3 & WLS Eq. 1a & W-FE Eq. $2 \mathrm{a}$ & W-RE Eq. 3a \\
\hline PCC_SE & $\begin{array}{c}0.193 \\
(0.49)\end{array}$ & $\begin{array}{c}-0.031 \\
(0.89)\end{array}$ & $\begin{array}{c}-0.031 \\
(0.86)\end{array}$ & $\begin{array}{c}0.311 \\
(0.51)\end{array}$ & $\begin{array}{c}-0.045 \\
(0.90)\end{array}$ & $\begin{array}{c}-0.045 \\
(0.87)\end{array}$ \\
\hline Years relative to 1990 & $\begin{array}{l}-0.002 \\
(0.00145)\end{array}$ & $\begin{array}{l}-0.002 \\
(0.001)\end{array}$ & $\begin{array}{c}-0.002 \\
(0.001)\end{array}$ & $\begin{array}{c}-0.003^{b} \\
(0.001)\end{array}$ & $\begin{array}{c}-0.002 \\
(0.002)\end{array}$ & $\begin{array}{r}-0.002 \\
(0.002)\end{array}$ \\
\hline WP & $\begin{array}{c}0.023 \\
(0.09)\end{array}$ & $\begin{array}{c}0.224^{a} \\
(0.02)\end{array}$ & $\begin{array}{c}0.223^{a} \\
(0.02)\end{array}$ & $\begin{array}{c}0.034 \\
(0.10)\end{array}$ & $\begin{array}{c}0.213^{a} \\
(0.02)\end{array}$ & $\begin{array}{r}0.213^{a} \\
(0.02)\end{array}$ \\
\hline Endogeneity & $\begin{array}{l}0.030 \\
(0.02)\end{array}$ & $\begin{array}{c}0.007 \\
(0.01)\end{array}$ & $\begin{array}{c}0.007 \\
(0.01)\end{array}$ & $\begin{array}{c}0.036^{c} \\
(0.01)\end{array}$ & $\begin{array}{c}0.005 \\
(0.01)\end{array}$ & $\begin{array}{r}0.005 \\
(0.01)\end{array}$ \\
\hline Meth_others & $\begin{array}{c}-0.196 \\
0.12)\end{array}$ & $\begin{array}{c}-0.0832^{a} \\
(0.01)\end{array}$ & $\begin{array}{c}-0.124 \\
(0.07)\end{array}$ & $\begin{array}{c}-0.294^{b} \\
(0.14)\end{array}$ & $\begin{array}{c}-0.083^{a} \\
(0.01)\end{array}$ & $\begin{array}{c}-0.083^{a} \\
(0.01)\end{array}$ \\
\hline Init_income & $\begin{array}{c}0.018 \\
(0.03)\end{array}$ & $\begin{array}{c}0.066 \\
(0.04)\end{array}$ & $\begin{array}{c}0.066^{c} \\
(0.04)\end{array}$ & $\begin{array}{c}0.073^{b} \\
(0.03)\end{array}$ & $\begin{array}{c}0.067 \\
(0.04)\end{array}$ & $\begin{array}{c}0.068^{c} \\
(0.04)\end{array}$ \\
\hline Investment & $\begin{array}{c}0.019 \\
(0.04)\end{array}$ & $\begin{array}{c}0.030 \\
(0.02)\end{array}$ & $\begin{array}{c}0.005 \\
(0.02)\end{array}$ & $\begin{array}{c}-0.014 \\
(0.03)\end{array}$ & $\begin{array}{c}0.032 \\
(0.02)\end{array}$ & $\begin{array}{r}0.032 \\
(0.02)\end{array}$ \\
\hline Openness & $\begin{array}{c}0.101^{a} \\
(0.03)\end{array}$ & $\begin{array}{c}-0.010 \\
(0.01)\end{array}$ & $\begin{array}{c}-0.010 \\
(0.02)\end{array}$ & $\begin{array}{c}0.068^{c} \\
(0.03)\end{array}$ & $\begin{array}{c}-0.012 \\
(0.01)\end{array}$ & $\begin{array}{c}-0.012 \\
(0.02)\end{array}$ \\
\hline Institutions & $\begin{array}{c}0.0007 \\
(0.04)\end{array}$ & $\begin{array}{c}-0.019 \\
(0.02)\end{array}$ & $\begin{array}{c}-0.019 \\
(0.02)\end{array}$ & $\begin{array}{c}0.029 \\
(0.04)\end{array}$ & $\begin{array}{c}-0.019 \\
(0.02)\end{array}$ & $\begin{array}{r}-0.02 \\
(0.02)\end{array}$ \\
\hline Human_k & $\begin{array}{c}-0.003 \\
(0.02)\end{array}$ & $\begin{array}{c}0.019^{c} \\
(0.01)\end{array}$ & $\begin{array}{c}0.02^{c} \\
(0.01)\end{array}$ & $\begin{array}{c}0.0009 \\
(0.02)\end{array}$ & $\begin{array}{c}0.019^{c} \\
(0.01)\end{array}$ & $\begin{array}{r}0.02^{c} \\
(0.01)\end{array}$ \\
\hline Physical_k & $\begin{array}{c}-0.025 \\
(0.04)\end{array}$ & $\begin{array}{c}0.002 \\
(0.02)\end{array}$ & $\begin{array}{c}0.002 \\
(0.02)\end{array}$ & $\begin{array}{c}-0.018 \\
(0.04)\end{array}$ & $\begin{array}{c}0.002 \\
(0.02)\end{array}$ & $\begin{array}{r}0.002 \\
(0.02)\end{array}$ \\
\hline Competitiveness & $\begin{array}{c}-0.062 \\
(0.04)\end{array}$ & $\begin{array}{c}-0.039 \\
(0.03)\end{array}$ & $\begin{array}{c}-0.039 \\
(0.03)\end{array}$ & $\begin{array}{c}-0.076 \\
(0.04)\end{array}$ & $\begin{array}{c}-0.038 \\
(0.03)\end{array}$ & $\begin{array}{c}-0.038 \\
(0.04)\end{array}$ \\
\hline Policy & $\begin{array}{c}-0.019 \\
(0.03)\end{array}$ & $\begin{array}{c}0.035^{b} \\
(0.01)\end{array}$ & $\begin{array}{c}0.035^{b} \\
(0.01)\end{array}$ & $\begin{array}{c}0.006 \\
(0.03)\end{array}$ & $\begin{array}{c}0.035^{b} \\
(0.01)\end{array}$ & $\begin{array}{c}0.035^{b} \\
(0.01)\end{array}$ \\
\hline Geo & $\begin{array}{c}-0.015 \\
(0.07)\end{array}$ & $\begin{array}{c}0.186^{a} \\
(0.05)\end{array}$ & $\begin{array}{c}0.186^{a} \\
(0.05)\end{array}$ & $\begin{array}{c}-0.002 \\
(0.09)\end{array}$ & $\begin{array}{c}0.178^{a} \\
(0.05)\end{array}$ & $\begin{array}{c}0.178^{a} \\
(0.05)\end{array}$ \\
\hline Time_series & $\begin{array}{c}0.018 \\
(0.02)\end{array}$ & $\begin{array}{c}0.032^{a} \\
(0.009)\end{array}$ & $\begin{array}{c}0.032^{a} \\
(0.009)\end{array}$ & $\begin{array}{c}0.035 \\
(0.02)\end{array}$ & $\begin{array}{c}0.029^{b} \\
(0.01)\end{array}$ & $\begin{array}{c}0.029^{a} \\
(0.01)\end{array}$ \\
\hline Cross & $\begin{array}{c}-0.091^{b} \\
(0.03)\end{array}$ & $\begin{array}{c}-0.091 \\
(0.07)\end{array}$ & $\begin{array}{c}-0.092 \\
(0.07)\end{array}$ & $\begin{array}{c}-0.106^{a} \\
(0.03)\end{array}$ & $\begin{array}{c}-0.092 \\
(0.08)\end{array}$ & $\begin{array}{c}-0.092 \\
(0.08)\end{array}$ \\
\hline SW & $\begin{array}{c}0.022 \\
(0.07)\end{array}$ & $\begin{array}{c}-0.126^{c} \\
(0.07)\end{array}$ & $\begin{array}{c}-0.125^{c} \\
(0.07)\end{array}$ & $\begin{array}{c}0.0558 \\
(0.08)\end{array}$ & $\begin{array}{c}-0.101 \\
(0.09)\end{array}$ & $\begin{array}{c}-0.100 \\
(0.1)\end{array}$ \\
\hline Lin_lin & $\begin{array}{c}-0.014 \\
(0.06)\end{array}$ & $\begin{array}{c}-3.08 \mathrm{e}-05 \\
(0.16)\end{array}$ & $\begin{array}{c}0.001 \\
(0.15)\end{array}$ & $\begin{array}{c}0.019 \\
(0.06)\end{array}$ & $\begin{array}{c}0.011 \\
(0.16)\end{array}$ & $\begin{array}{r}0.012 \\
(0.15)\end{array}$ \\
\hline Log_log & $\begin{array}{c}0.244^{a} \\
(0.04)\end{array}$ & $\begin{array}{c}0.386^{a} \\
(0.09)\end{array}$ & $\begin{array}{c}0.386^{a} \\
(0.09)\end{array}$ & $\begin{array}{c}0.178^{a} \\
(0.04)\end{array}$ & $\begin{array}{c}0.189^{a} \\
(0.05)\end{array}$ & $\begin{array}{c}0.190^{a} \\
(0.05)\end{array}$ \\
\hline D_events & $\begin{array}{c}-0.13 \\
(0.10)\end{array}$ & $\begin{array}{c}0.032 \\
(0.02)\end{array}$ & $\begin{array}{c}0.032^{c} \\
(0.02)\end{array}$ & $\begin{array}{c}-0.175 \\
(0.11)\end{array}$ & $\begin{array}{c}0.025 \\
(0.02)\end{array}$ & $\begin{array}{r}0.026 \\
(0.02)\end{array}$ \\
\hline D_geo & $\begin{array}{c}0.046 \\
(0.03)\end{array}$ & $\begin{array}{c}0.003 \\
(0.01)\end{array}$ & $\begin{array}{c}0.004 \\
(0.02)\end{array}$ & $\begin{array}{c}0.061^{b} \\
(0.02)\end{array}$ & $\begin{array}{c}0.002 \\
(0.01)\end{array}$ & $\begin{array}{r}0.002 \\
(0.02)\end{array}$ \\
\hline D_time & $\begin{array}{c}-0.085^{b} \\
(0.04)\end{array}$ & $\begin{array}{c}0.021 \\
(0.02)\end{array}$ & $\begin{array}{c}0.021 \\
(0.02)\end{array}$ & $\begin{array}{c}-0.074^{c} \\
(0.03)\end{array}$ & $\begin{array}{c}0.021 \\
(0.02)\end{array}$ & $\begin{array}{r}0.021 \\
(0.02)\end{array}$ \\
\hline D_instit & $\begin{array}{c}-0.033 \\
(0.07)\end{array}$ & $\begin{array}{c}0.002 \\
(0.03)\end{array}$ & $\begin{array}{c}0.002 \\
(0.03)\end{array}$ & $\begin{array}{c}-0.033 \\
(0.06)\end{array}$ & $\begin{array}{c}0.0158 \\
(0.03)\end{array}$ & $\begin{array}{r}0.016 \\
(0.04)\end{array}$ \\
\hline D_political & $\begin{array}{c}-0.128 \\
(0.08)\end{array}$ & $\begin{array}{c}-0.001 \\
(0.01)\end{array}$ & $\begin{array}{c}-0.001 \\
(0.01)\end{array}$ & $\begin{array}{c}-0.113 \\
(0.10)\end{array}$ & $\begin{array}{c}-0.00246 \\
(0.01)\end{array}$ & $\begin{array}{c}-0.002 \\
(0.01)\end{array}$ \\
\hline D_charact & $\begin{array}{c}-0.032 \\
(0.03)\end{array}$ & $\begin{array}{c}0.027^{c} \\
(0.01)\end{array}$ & $\begin{array}{c}0.027^{b} \\
(0.01)\end{array}$ & $\begin{array}{c}0.004 \\
(0.03)\end{array}$ & $\begin{array}{c}0.027^{c} \\
(0.01)\end{array}$ & $\begin{array}{c}0.027^{b} \\
(0.01)\end{array}$ \\
\hline Developed & $\begin{array}{c}-0.087 \\
(0.05)\end{array}$ & $\begin{array}{c}0.134^{a} \\
(0.03)\end{array}$ & $\begin{array}{c}0.133^{a} \\
(0.04)\end{array}$ & $\begin{array}{c}-0.210^{b} \\
(0.08)\end{array}$ & $\begin{array}{c}0.137^{a} \\
(0.04)\end{array}$ & $\begin{array}{c}0.137^{a} \\
(0.04)\end{array}$ \\
\hline Developing & $\begin{array}{c}0.027 \\
(0.04)\end{array}$ & $\begin{array}{c}-0.003 \\
(0.02)\end{array}$ & $\begin{array}{c}-0.004 \\
(0.02)\end{array}$ & $\begin{array}{c}-0.006 \\
(0.04)\end{array}$ & $\begin{array}{c}-0.002 \\
(0.02)\end{array}$ & $\begin{array}{c}-0.002 \\
(0.02)\end{array}$ \\
\hline Interact_instit & $\begin{array}{c}0.017 \\
(0.02)\end{array}$ & $\begin{array}{c}-0.013 \\
(0.01)\end{array}$ & $\begin{array}{c}-0.013 \\
(0.01)\end{array}$ & $\begin{array}{c}0.023 \\
(0.02)\end{array}$ & $\begin{array}{c}-0.012 \\
(0.01)\end{array}$ & $\begin{array}{c}-0.012 \\
(0.02)\end{array}$ \\
\hline Interact_others & $\begin{array}{c}0.001 \\
(0.04)\end{array}$ & $\begin{array}{c}0.075^{a} \\
(0.02)\end{array}$ & $\begin{array}{c}0.076^{b} \\
(0.02)\end{array}$ & $\begin{array}{c}0.0069 \\
(0.04)\end{array}$ & $\begin{array}{c}0.077^{a} \\
(0.01)\end{array}$ & $\begin{array}{r}0.078^{a} \\
(0.02)\end{array}$ \\
\hline Replication & $\begin{array}{c}-0.051 \\
(0.15)\end{array}$ & $\begin{array}{c}-0.075 \\
(0.04\end{array}$ & $\begin{array}{c}-0.075 \\
(0.05)\end{array}$ & $\begin{array}{c}-0.049 \\
(0.16)\end{array}$ & $\begin{array}{c}-0.076 \\
(0.04)\end{array}$ & $\begin{array}{c}-0.076 \\
(0.05)\end{array}$ \\
\hline Abundance & $\begin{array}{c}0.017 \\
(0.02)\end{array}$ & $\begin{array}{c}-0.009 \\
(0.01)\end{array}$ & $\begin{array}{c}-0.009 \\
(0.01)\end{array}$ & & & \\
\hline Employment & & & & $\begin{array}{c}0.170^{b} \\
(0.06)\end{array}$ & - & $\begin{array}{r}-0.07 \\
(0.13)\end{array}$ \\
\hline Primary_Exports & & & & $\begin{array}{c}-0.111^{b} \\
(0.05)\end{array}$ & $\begin{array}{c}-0.079 \\
(0.05)\end{array}$ & $\begin{array}{c}-0.079 \\
(0.05)\end{array}$ \\
\hline Natural_Capital & & & & $\begin{array}{c}0.281^{a} \\
(0.07)\end{array}$ & $\begin{array}{c}0.242^{a} \\
(0.05)\end{array}$ & $\begin{array}{r}0.242^{c} \\
(0.05)\end{array}$ \\
\hline Rents & & & & $\begin{array}{c}-0.002 \\
(0.01)\end{array}$ & $\begin{array}{c}-0.006^{c} \\
(0.003)\end{array}$ & $\begin{array}{r}-0.006^{c} \\
(0.003)\end{array}$ \\
\hline Reserves & & & & $\begin{array}{c}0.156^{b} \\
(0.07)\end{array}$ & $\begin{array}{c}0.037 \\
(0.08)\end{array}$ & $\begin{array}{r}0.038 \\
(0.08)\end{array}$ \\
\hline Production & & & & $\begin{array}{c}0.057 \\
(0.05)\end{array}$ & $\begin{array}{c}0.019 \\
(0.03)\end{array}$ & $\begin{array}{r}0.019 \\
(0.03)\end{array}$ \\
\hline Constant & $\begin{array}{c}-0.113^{a} \\
(0.03)\end{array}$ & $\begin{array}{c}-0.152^{a} \\
(0.03) \\
\end{array}$ & $\begin{array}{c}-0.135^{b} \\
(0.06) \\
\end{array}$ & $\begin{array}{c}-0.139^{a} \\
(0.04) \\
\end{array}$ & $\begin{array}{c}-0.171^{a} \\
(0.03)\end{array}$ & $\begin{array}{c}-0.146^{a} \\
(0.07) \\
\end{array}$ \\
\hline Observations & 1,405 & 1,405 & 1,405 & 1,405 & 1,405 & 1,405 \\
\hline R-squared & 0.401 & 0.676 & & 0.437 & 0.678 & \\
\hline Number of id_paper & 67 & 67 & 67 & 67 & 67 & 67 \\
\hline
\end{tabular}


Table 5: Results - Appropriability

Point vs. Diffuse

Detailed RESOURCES

VARIABLES WLS Eq. 1 W-FE Eq. 2 W-RE Eq. 3 WLS Eq. 1a W-FE Eq. 2a W-RE Eq. 3a

\begin{tabular}{|c|c|c|c|c|c|c|}
\hline PCC_SE & $\begin{array}{c}0.115 \\
(0.47)\end{array}$ & $\begin{array}{c}-0.061 \\
(0.89)\end{array}$ & $\begin{array}{c}-0.061 \\
(0.86)\end{array}$ & $\begin{array}{c}-0.019 \\
(0.45)\end{array}$ & $\begin{array}{c}-0.076 \\
(0.90)\end{array}$ & $\begin{array}{c}-0.100 \\
(0.85)\end{array}$ \\
\hline Years relative to 1990 & $\begin{array}{c}-0.002 \\
(0.00139)\end{array}$ & $\begin{array}{c}-0.002 \\
(0.002)\end{array}$ & $\begin{array}{c}-0.001 \\
(0.002)\end{array}$ & $\begin{array}{c}-0.002 \\
(0.001)\end{array}$ & $\begin{array}{c}-0.002 \\
(0.001)\end{array}$ & $\begin{array}{r}-0.002^{c} \\
(0.001)\end{array}$ \\
\hline WP & $\begin{array}{c}0.027 \\
(0.09)\end{array}$ & $\begin{array}{c}0.226^{a} \\
(0.02)\end{array}$ & $\begin{array}{c}0.225^{a} \\
(0.02)\end{array}$ & $\begin{array}{c}0.012 \\
(0.09)\end{array}$ & $\begin{array}{c}0.224^{a} \\
(0.01)\end{array}$ & $\begin{array}{c}0.221^{a} \\
(0.01)\end{array}$ \\
\hline Endogeneity & $\begin{array}{c}0.032^{c} \\
(0.01)\end{array}$ & $\begin{array}{c}0.007 \\
(0.01)\end{array}$ & $\begin{array}{c}0.007 \\
(0.01)\end{array}$ & $\begin{array}{c}0.033^{c} \\
(0.01)\end{array}$ & $\begin{array}{c}0.008 \\
(0.01)\end{array}$ & $\begin{array}{c}-0.020 \\
(0.01)\end{array}$ \\
\hline Meth_others & $\begin{array}{c}-0.177 \\
(0.12)\end{array}$ & $\begin{array}{c}-0.083^{a} \\
(0.01)\end{array}$ & $\begin{array}{c}-0.083^{a} \\
(0.01)\end{array}$ & $\begin{array}{c}-0.175 \\
(0.12)\end{array}$ & $\begin{array}{c}-0.081^{a} \\
(0.01)\end{array}$ & $\begin{array}{c}-0.101^{a} \\
(0.02)\end{array}$ \\
\hline Init_income & $\begin{array}{c}0.025 \\
(0.03)\end{array}$ & $\begin{array}{c}0.066 \\
(0.04)\end{array}$ & $\begin{array}{c}0.066^{c} \\
(0.04)\end{array}$ & $\begin{array}{c}0.040 \\
(0.03)\end{array}$ & $\begin{array}{c}0.072^{c} \\
(0.04)\end{array}$ & $\begin{array}{r}0.072^{c} \\
(0.04)\end{array}$ \\
\hline Investment & $\begin{array}{c}0.016 \\
(0.03)\end{array}$ & $\begin{array}{r}0.029 \\
(0.02)\end{array}$ & $\begin{array}{c}0.029 \\
(0.02)\end{array}$ & $\begin{array}{c}0.008 \\
(0.03)\end{array}$ & $\begin{array}{c}0.031 \\
(0.02)\end{array}$ & $\begin{array}{r}0.030 \\
(0.02)\end{array}$ \\
\hline Openness & $\begin{array}{c}0.107^{a} \\
(0.03)\end{array}$ & $\begin{array}{c}-0.010 \\
(0.01)\end{array}$ & $\begin{array}{c}-0.011 \\
(0.01)\end{array}$ & $\begin{array}{c}0.081^{b} \\
(0.03)\end{array}$ & $\begin{array}{c}-0.011 \\
(0.01)\end{array}$ & $\begin{array}{r}-0.011 \\
(0.02)\end{array}$ \\
\hline Institutions & $\begin{array}{c}0.007 \\
(0.04)\end{array}$ & $\begin{array}{c}-0.019 \\
(0.02)\end{array}$ & $\begin{array}{c}-0.019 \\
(0.02)\end{array}$ & $\begin{array}{r}0.021 \\
(0.04)\end{array}$ & $\begin{array}{c}-0.015 \\
(0.02)\end{array}$ & $\begin{array}{r}-0.026 \\
(0.02)\end{array}$ \\
\hline Human_k & $\begin{array}{c}0.003 \\
(0.02)\end{array}$ & $\begin{array}{c}0.019^{c} \\
(0.01)\end{array}$ & $\begin{array}{c}0.02^{c} \\
(0.01)\end{array}$ & $\begin{array}{c}0.015 \\
(0.02)\end{array}$ & $\begin{array}{c}0.026^{b} \\
(0.01)\end{array}$ & $\begin{array}{r}0.016 \\
(0.01)\end{array}$ \\
\hline Physical_k & $\begin{array}{c}-0.023 \\
(0.04)\end{array}$ & $\begin{array}{c}0.002 \\
(0.02)\end{array}$ & $\begin{array}{c}0.002 \\
(0.02)\end{array}$ & $\begin{array}{c}0.001 \\
(0.04)\end{array}$ & $\begin{array}{c}0.0015 \\
(0.02)\end{array}$ & $\begin{array}{c}-0.013 \\
(0.03)\end{array}$ \\
\hline Competitiveness & $\begin{array}{c}-0.062 \\
(0.04\end{array}$ & $\begin{array}{c}-0.039 \\
(0.03)\end{array}$ & $\begin{array}{c}-0.039 \\
(0.03)\end{array}$ & $\begin{array}{c}-0.062 \\
(0.04)\end{array}$ & $\begin{array}{c}-0.041 \\
(0.03)\end{array}$ & $\begin{array}{r}-0.043 \\
(0.03)\end{array}$ \\
\hline Policy & $\begin{array}{c}-0.014 \\
(0.03)\end{array}$ & $\begin{array}{c}0.035^{b} \\
(0.01)\end{array}$ & $\begin{array}{c}0.035^{b} \\
(0.01)\end{array}$ & $\begin{array}{c}-0.027 \\
(0.03)\end{array}$ & $\begin{array}{c}0.034^{b} \\
(0.01)\end{array}$ & $\begin{array}{r}0.035^{b} \\
(0.01)\end{array}$ \\
\hline Geo & $\begin{array}{c}0.002 \\
(0.06)\end{array}$ & $\begin{array}{c}0.185^{a} \\
(0.05)\end{array}$ & $\begin{array}{c}0.185^{a} \\
(0.05)\end{array}$ & $\begin{array}{c}-0.053 \\
(0.07)\end{array}$ & $\begin{array}{c}0.185^{a} \\
(0.05)\end{array}$ & $\begin{array}{c}0.184^{a} \\
(0.05)\end{array}$ \\
\hline Time_series & $\begin{array}{c}0.021 \\
(0.02)\end{array}$ & $\begin{array}{c}0.026^{b} \\
(0.01)\end{array}$ & $\begin{array}{c}0.027^{b} \\
(0.01)\end{array}$ & $\begin{array}{c}0.026 \\
(0.02)\end{array}$ & $\begin{array}{c}0.032^{a} \\
(0.01)\end{array}$ & $\begin{array}{r}0.026^{b} \\
(0.01)\end{array}$ \\
\hline Cross & $\begin{array}{c}-0.081^{b} \\
(0.03)\end{array}$ & $\begin{array}{c}-0.091 \\
(0.08)\end{array}$ & $\begin{array}{c}-0.091 \\
(0.07)\end{array}$ & $\begin{array}{c}-0.076^{b} \\
(0.03)\end{array}$ & $\begin{array}{c}-0.088 \\
(0.08)\end{array}$ & $\begin{array}{r}-0.085 \\
(0.07)\end{array}$ \\
\hline SW & $\begin{array}{c}0.028 \\
(0.07)\end{array}$ & $\begin{array}{c}-0.117 \\
(0.07)\end{array}$ & $\begin{array}{c}-0.117 \\
(0.07)\end{array}$ & $\begin{array}{c}0.0302 \\
(0.07)\end{array}$ & $\begin{array}{c}-0.129^{c} \\
(0.07)\end{array}$ & $\begin{array}{c}-0.130^{c} \\
(0.07)\end{array}$ \\
\hline Lin_lin & $\begin{array}{c}-0.019 \\
(0.06)\end{array}$ & $\begin{array}{c}0.001 \\
(0.16)\end{array}$ & $\begin{array}{c}0.003 \\
(0.16)\end{array}$ & $\begin{array}{c}-0.020 \\
(0.07)\end{array}$ & $\begin{array}{c}-0.011 \\
(0.17)\end{array}$ & $\begin{array}{r}-0.018 \\
(0.17)\end{array}$ \\
\hline Log_log & $\begin{array}{c}0.253^{a} \\
(0.04)\end{array}$ & $\begin{array}{c}0.384^{a} \\
(0.09)\end{array}$ & $\begin{array}{c}0.384^{a} \\
(0.09)\end{array}$ & $\begin{array}{c}0.242^{a} \\
(0.03)\end{array}$ & $\begin{array}{c}0.237^{b} \\
(0.09)\end{array}$ & $\begin{array}{r}0.235^{a} \\
(0.09)\end{array}$ \\
\hline D_events & $\begin{array}{c}-0.123 \\
(0.10)\end{array}$ & $\begin{array}{c}0.029 \\
(0.02)\end{array}$ & $\begin{array}{c}0.030 \\
(0.02)\end{array}$ & $\begin{array}{c}-0.123 \\
(0.10)\end{array}$ & $\begin{array}{c}0.034 \\
(0.02)\end{array}$ & $\begin{array}{r}0.032 \\
(0.02)\end{array}$ \\
\hline D_geo & $\begin{array}{c}0.048^{c} \\
(0.02)\end{array}$ & $\begin{array}{c}0.003 \\
(0.01)\end{array}$ & $\begin{array}{c}0.003 \\
(0.02)\end{array}$ & $\begin{array}{c}0.051^{c} \\
(0.02)\end{array}$ & $\begin{array}{c}0.001 \\
(0.01)\end{array}$ & $\begin{array}{r}0.003 \\
(0.01)\end{array}$ \\
\hline D_time & $\begin{array}{c}-0.091^{b} \\
(0.03)\end{array}$ & $\begin{array}{c}0.021 \\
(0.02)\end{array}$ & $\begin{array}{c}0.021 \\
(0.02)\end{array}$ & $\begin{array}{c}-0.089^{b} \\
(0.04)\end{array}$ & $\begin{array}{c}0.021 \\
(0.02)\end{array}$ & $\begin{array}{c}0.0217 \\
(0.02)\end{array}$ \\
\hline D_instit & $\begin{array}{c}-0.024 \\
(0.07)\end{array}$ & $\begin{array}{c}0.003 \\
(0.03)\end{array}$ & $\begin{array}{c}0.003 \\
(0.03)\end{array}$ & $\begin{array}{c}-0.020 \\
(0.07)\end{array}$ & $\begin{array}{c}-0.033 \\
(0.03)\end{array}$ & $\begin{array}{c}-0.036 \\
(0.03)\end{array}$ \\
\hline D_political & $\begin{array}{c}-0.120 \\
(0.08)\end{array}$ & $\begin{array}{c}-0.001 \\
(0.01)\end{array}$ & $\begin{array}{c}-0.001 \\
(0.01)\end{array}$ & $\begin{array}{c}-0.123 \\
(0.07)\end{array}$ & $\begin{array}{c}-0.001 \\
(0.01)\end{array}$ & $\begin{array}{c}-0.001 \\
(0.01)\end{array}$ \\
\hline D_charact & $\begin{array}{c}-0.025 \\
(0.03)\end{array}$ & $\begin{array}{c}0.026^{c} \\
(0.01)\end{array}$ & $\begin{array}{c}0.027^{b} \\
(0.01)\end{array}$ & $\begin{array}{c}-0.036 \\
(0.04)\end{array}$ & $\begin{array}{c}0.032^{b} \\
(0.01)\end{array}$ & $\begin{array}{r}0.031^{a} \\
(0.01)\end{array}$ \\
\hline Developed & $\begin{array}{c}-0.096^{c} \\
(0.05)\end{array}$ & $\begin{array}{c}0.135^{a} \\
(0.03)\end{array}$ & $\begin{array}{c}0.135^{a} \\
(0.04)\end{array}$ & $\begin{array}{c}-0.089 \\
(0.05)\end{array}$ & $\begin{array}{c}0.133^{a} \\
(0.03)\end{array}$ & $\begin{array}{r}0.132^{a} \\
(0.03)\end{array}$ \\
\hline Developing & $\begin{array}{c}0.007 \\
(0.04)\end{array}$ & $\begin{array}{c}-0.004 \\
(0.02)\end{array}$ & $\begin{array}{c}-0.004 \\
(0.02)\end{array}$ & $\begin{array}{c}0.042 \\
(0.04)\end{array}$ & $\begin{array}{c}-0.001 \\
(0.02)\end{array}$ & $\begin{array}{c}-0.0005 \\
(0.02)\end{array}$ \\
\hline Interact_instit & $\begin{array}{c}0.011 \\
(0.02)\end{array}$ & $\begin{array}{c}-0.011 \\
(0.01)\end{array}$ & $\begin{array}{c}0.011 \\
(0.02)\end{array}$ & $\begin{array}{c}0.019 \\
(0.02)\end{array}$ & $\begin{array}{c}0.002 \\
(0.01)\end{array}$ & $\begin{array}{r}0.007 \\
(0.02)\end{array}$ \\
\hline Interact_others & $\begin{array}{c}0.009 \\
(0.04)\end{array}$ & $\begin{array}{c}0.077^{a} \\
(0.01)\end{array}$ & $\begin{array}{c}0.077^{a} \\
(0.02)\end{array}$ & $\begin{array}{c}0.019 \\
(0.04)\end{array}$ & $\begin{array}{c}0.078^{a} \\
(0.01)\end{array}$ & $\begin{array}{r}0.079^{a} \\
(0.02)\end{array}$ \\
\hline Replication & $\begin{array}{c}-0.028 \\
(0.16)\end{array}$ & $\begin{array}{c}-0.075 \\
(0.04)\end{array}$ & $\begin{array}{c}-0.075 \\
(0.04)\end{array}$ & $\begin{array}{c}-0.029 \\
(0.16)\end{array}$ & $\begin{array}{c}-0.074 \\
(0.04)\end{array}$ & $\begin{array}{c}-0.070 \\
(0.04)\end{array}$ \\
\hline Point & $\begin{array}{c}0.041^{b} \\
(0.02)\end{array}$ & $\begin{array}{c}0.011^{b} \\
(0.005)\end{array}$ & $\begin{array}{c}0.012^{b} \\
(0.005)\end{array}$ & & & \\
\hline Diffuse & $\begin{array}{c}0.063^{b} \\
(0.02)\end{array}$ & $\begin{array}{c}0.032^{a} \\
(0.008)\end{array}$ & $\begin{array}{c}0.033^{a} \\
(0.008)\end{array}$ & & & \\
\hline Agri & & & & $\begin{array}{c}0.063^{a} \\
(0.019)\end{array}$ & $\begin{array}{c}0.049^{a} \\
(0.008)\end{array}$ & $\begin{array}{c}0.05^{a} \\
(0.008)\end{array}$ \\
\hline Food & & & & $\begin{array}{c}0.029 \\
(0.02)\end{array}$ & $\begin{array}{c}-0.002 \\
(0.007)\end{array}$ & $\begin{array}{r}-0.001 \\
(0.008)\end{array}$ \\
\hline Fuel & & & & $\begin{array}{c}0.057^{b} \\
(0.02)\end{array}$ & $\begin{array}{c}0.021^{a} \\
(0.007)\end{array}$ & $\begin{array}{r}0.022^{a} \\
(0.007)\end{array}$ \\
\hline Ore_mineral & & & & $\begin{array}{c}-0.008 \\
(0.01)\end{array}$ & $\begin{array}{c}-0.0226^{b} \\
(0.009)\end{array}$ & $\begin{array}{r}-0.022^{b} \\
(0.009)\end{array}$ \\
\hline Forestry & & & & $\begin{array}{c}0.031^{b} \\
(0.01)\end{array}$ & $\begin{array}{c}0.020^{a} \\
(0.007)\end{array}$ & $\begin{array}{r}0.021^{a} \\
(0.007)\end{array}$ \\
\hline Subsoil & & & & $\begin{array}{c}0.290^{a} \\
(0.06)\end{array}$ & $\begin{array}{c}0.206^{a} \\
(0.02)\end{array}$ & $\begin{array}{r}0.206^{a} \\
(0.02)\end{array}$ \\
\hline Precious_met & & & & $\begin{array}{c}-0.023 \\
(0.09)\end{array}$ & $\begin{array}{c}-0.062 \\
(0.05)\end{array}$ & $\begin{array}{c}-0.061 \\
(0.05)\end{array}$ \\
\hline Constant & $\begin{array}{c}-0.138^{a} \\
0.04)\end{array}$ & $\begin{array}{c}-0.163^{a} \\
(0.03)\end{array}$ & $\begin{array}{c}-0.143^{b} \\
(0.06)\end{array}$ & $\begin{array}{c}-0.134^{a} \\
(0.03)\end{array}$ & $\begin{array}{c}-0.140^{a} \\
(0.03)\end{array}$ & $\begin{array}{c}-0.100^{c} \\
(0.05)\end{array}$ \\
\hline Observations & 1,405 & 1,405 & 1,405 & 1,405 & 1,405 & 1,405 \\
\hline R-squared & 0.413 & 0.677 & & 0.434 & 0.688 & \\
\hline Number of id_paper & 67 & 67 & 67 & 67 & 67 & 67 \\
\hline
\end{tabular}


Table 6: Variables

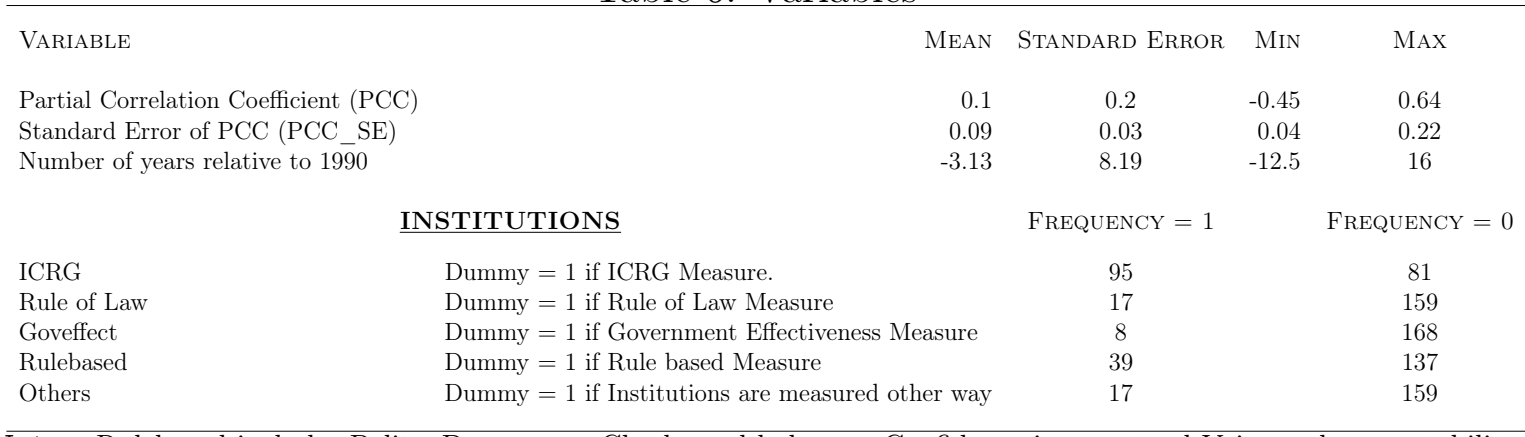

Notes. Rulebased includes Polity, Democracy, Checks and balances, Confidence in court and Voice and accountability.

Notes.Others includes Corruption, Economic Freedom and Government size.

Table 7: Results - Appropriability and Institutions

\begin{tabular}{|c|c|c|c|c|c|c|}
\hline \multirow[b]{2}{*}{ VARIABLES } & \multicolumn{3}{|c|}{ PoInT vs. Diffuse } & \multicolumn{3}{|c|}{ DETAILED RESOURCES } \\
\hline & WLS Eq. 1 & W-FE Eq. 2 & W-RE Eq. 3 & WLS Eq. 1a & W-FE Eq. $2 \mathrm{a}$ & W-RE Eq. $3 \mathrm{a}$ \\
\hline PCC_SE & $\begin{array}{c}2.249^{a} \\
(0.46)\end{array}$ & $\begin{array}{c}0.038 \\
(0.75)\end{array}$ & $\begin{array}{c}0.034 \\
(0.68)\end{array}$ & $\begin{array}{c}2.095^{a} \\
(0.57)\end{array}$ & $\begin{array}{c}-0.259 \\
(0.60)\end{array}$ & $\begin{array}{c}-0.261 \\
(0.54)\end{array}$ \\
\hline Years relative to 1990 & $\begin{array}{c}-0.003 \\
(0.003)\end{array}$ & $\begin{array}{c}-0.008 \\
(0.01)\end{array}$ & $\begin{array}{c}-0.008 \\
(0.01)\end{array}$ & $\begin{array}{c}-0.001 \\
(0.003)\end{array}$ & $\begin{array}{c}-0.002 \\
(0.01)\end{array}$ & $\begin{array}{c}-0.002 \\
(0.01)\end{array}$ \\
\hline WP & $\begin{array}{c}-0.314^{a} \\
(0.09)\end{array}$ & & $\begin{array}{c}-0.117 \\
(0.16)\end{array}$ & $\begin{array}{c}-0.266^{a} \\
(0.08)\end{array}$ & & $\begin{array}{c}-0.093 \\
(0.16)\end{array}$ \\
\hline Endogeneity & $\begin{array}{c}0.016 \\
(0.03)\end{array}$ & $\begin{array}{c}-0.140^{b} \\
(0.05)\end{array}$ & $\begin{array}{c}-0.140^{a} \\
(0.04)\end{array}$ & $\begin{array}{c}-0.025 \\
(0.03)\end{array}$ & $\begin{array}{c}-0.119^{b} \\
(0.05)\end{array}$ & $\begin{array}{c}-0.119^{b} \\
(0.05)\end{array}$ \\
\hline SW & $\begin{array}{c}0.022 \\
(0.11)\end{array}$ & $\begin{array}{c}-0.407^{a} \\
(0.02)\end{array}$ & $\begin{array}{c}-0.406^{a} \\
(0.02)\end{array}$ & $\begin{array}{c}0.032 \\
(0.09)\end{array}$ & $\begin{array}{c}-0.348^{a} \\
(0.02)\end{array}$ & $\begin{array}{c}-0.347^{a} \\
(0.01)\end{array}$ \\
\hline Log_log & $\begin{array}{c}-0.229^{c} \\
(0.11)\end{array}$ & $\begin{array}{c}-0.981^{a} \\
(0.01)\end{array}$ & $\begin{array}{c}-0.980^{a} \\
(0.01)\end{array}$ & $\begin{array}{c}-0.204^{c} \\
(0.09)\end{array}$ & $\begin{array}{c}-0.973^{a} \\
(0.01)\end{array}$ & $\begin{array}{c}-0.971^{a} \\
(0.01)\end{array}$ \\
\hline Developing & $\begin{array}{c}0.048 \\
(0.05)\end{array}$ & $\begin{array}{c}0.026 \\
(0.01)\end{array}$ & $\begin{array}{c}0.026^{c} \\
(0.01)\end{array}$ & $\begin{array}{r}0.045 \\
(0.04)\end{array}$ & $\begin{array}{c}0.0223 \\
(0.01)\end{array}$ & $\begin{array}{c}0.022^{c} \\
(0.01)\end{array}$ \\
\hline Developed & $\begin{array}{c}0.009 \\
(0.15)\end{array}$ & $\begin{array}{c}-0.064 \\
(0.11)\end{array}$ & $\begin{array}{c}-0.064 \\
(0.1)\end{array}$ & $\begin{array}{c}-0.033 \\
(0.13)\end{array}$ & $\begin{array}{c}-0.070 \\
(0.10)\end{array}$ & $\begin{array}{c}-0.0704 \\
(0.09)\end{array}$ \\
\hline Rol & $\begin{array}{c}-0.106^{c} \\
(0.05)\end{array}$ & $\begin{array}{c}0.019 \\
(0.02)\end{array}$ & $\begin{array}{c}0.019 \\
(0.02)\end{array}$ & $\begin{array}{c}-0.093^{c} \\
(0.05)\end{array}$ & $\begin{array}{c}0.037^{c} \\
(0.02)\end{array}$ & $\begin{array}{r}0.037^{b} \\
(0.01)\end{array}$ \\
\hline Rulebased & $\begin{array}{c}-0.143^{b} \\
(0.05)\end{array}$ & $\begin{array}{c}-0.004 \\
(0.02)\end{array}$ & $\begin{array}{c}-0.004 \\
(0.02)\end{array}$ & $\begin{array}{c}-0.101^{c} \\
(0.05)\end{array}$ & $\begin{array}{r}0.028 \\
(0.02)\end{array}$ & $\begin{array}{r}0.028 \\
(0.02)\end{array}$ \\
\hline Goveffect & $\begin{array}{c}-0.215^{a} \\
(0.05)\end{array}$ & $\begin{array}{c}-0.068^{c} \\
(0.03)\end{array}$ & $\begin{array}{c}-0.068^{b} \\
(0.03)\end{array}$ & $\begin{array}{c}-0.193^{a} \\
(0.04)\end{array}$ & $\frac{-0.055^{c}}{(0.02)}$ & $\begin{array}{c}-0.055^{b} \\
(0.02)\end{array}$ \\
\hline Others & $\begin{array}{c}-0.113 \\
(0.07)\end{array}$ & $\begin{array}{c}0.008 \\
(0.02)\end{array}$ & $\begin{array}{c}0.008 \\
(0.02)\end{array}$ & $\begin{array}{c}-0.110^{c} \\
(0.05)\end{array}$ & $\begin{array}{r}0.013 \\
(0.02)\end{array}$ & $\begin{array}{c}0.013 \\
(0.02)\end{array}$ \\
\hline Panel & $\begin{array}{c}0.083 \\
(0.08)\end{array}$ & $\begin{array}{c}-0.092^{b} \\
(0.03)\end{array}$ & $\begin{array}{c}-0.092^{a} \\
(0.03)\end{array}$ & $\begin{array}{r}0.066 \\
(0.08)\end{array}$ & $\begin{array}{c}-0.101^{a} \\
(0.02)\end{array}$ & $\begin{array}{c}-0.101^{a} \\
(0.02)\end{array}$ \\
\hline Point & $\begin{array}{c}-0.009 \\
(0.03)\end{array}$ & $\begin{array}{l}0.008 \\
(0.006)\end{array}$ & $\begin{array}{r}0.008 \\
(0.006)\end{array}$ & & & \\
\hline Diffuse & $\begin{array}{c}0.016 \\
(0.07)\end{array}$ & $\begin{array}{c}-0.016^{b} \\
(0.007)\end{array}$ & $\begin{array}{r}-0.016^{b} \\
(0.006)\end{array}$ & & & \\
\hline Agri & & & & $\begin{array}{c}-0.055^{c} \\
(0.02)\end{array}$ & $\begin{array}{c}-0.044^{a} \\
(0.01)\end{array}$ & $\begin{array}{r}-0.045^{a} \\
(0.009)\end{array}$ \\
\hline Food & & & & $\begin{array}{c}-0.031 \\
(0.02)\end{array}$ & $\begin{array}{c}-0.021^{c} \\
(0.01)\end{array}$ & $\begin{array}{r}-0.021^{b} \\
(0.009)\end{array}$ \\
\hline Fuel & & & & $\begin{array}{c}-0.051^{b} \\
(0.02)\end{array}$ & $\begin{array}{c}-0.051^{a} \\
(0.008)\end{array}$ & $\begin{array}{r}-0.051^{a} \\
(0.008)\end{array}$ \\
\hline Ore_mineral & & & & $\begin{array}{c}0.098^{a} \\
(0.02)\end{array}$ & $\begin{array}{c}0.066^{b} \\
(0.03)\end{array}$ & $\begin{array}{r}0.066^{b} \\
(0.02)\end{array}$ \\
\hline Forestry & & & & $\begin{array}{c}-0.098^{a} \\
(0.03)\end{array}$ & $\begin{array}{c}-0.075^{a} \\
(0.008)\end{array}$ & $\begin{array}{r}-0.075^{a} \\
(0.007)\end{array}$ \\
\hline Subsoil & & & & $\begin{array}{c}-0.286^{a} \\
(0.07)\end{array}$ & $\begin{array}{c}0.102^{a} \\
(0.01)\end{array}$ & $\begin{array}{r}0.102^{a} \\
(0.01)\end{array}$ \\
\hline Constant & $\begin{array}{c}-0.028 \\
(0.04)\end{array}$ & $\begin{array}{c}0.328^{a} \\
(0.06)\end{array}$ & $\begin{array}{c}0.524^{a} \\
(0.13)\end{array}$ & $\begin{array}{c}-0.020 \\
(0.04)\end{array}$ & $\begin{array}{c}0.343^{a} \\
(0.07)\end{array}$ & $\begin{array}{c}0.535^{a} \\
(0.14)\end{array}$ \\
\hline Observations & 176 & 176 & 176 & 176 & 176 & 176 \\
\hline R-squared & 0.350 & 0.735 & & 0.470 & 0.771 & \\
\hline Number of groups & 17 & 17 & 17 & 17 & 17 & 17 \\
\hline
\end{tabular}




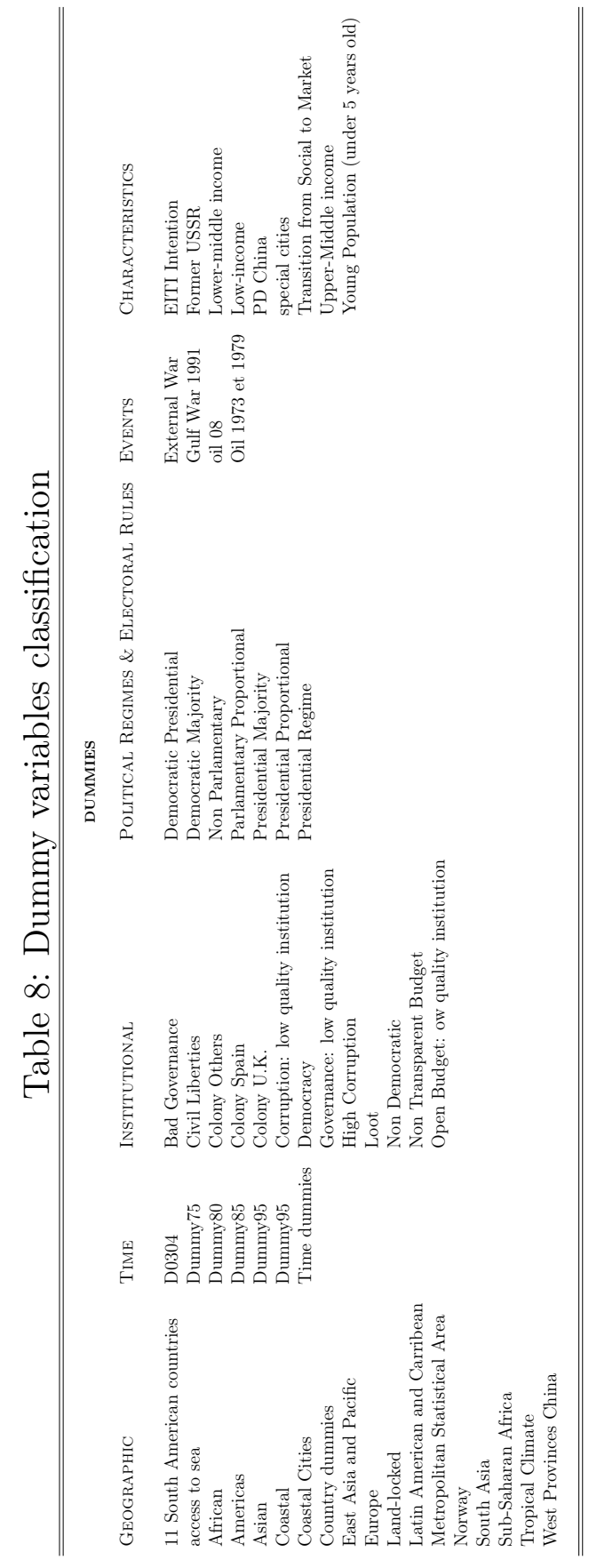

